\title{
Sludge Displacement Verification for Reducing Grout Report
}

by

T. B. Caldwell

Westinghouse Savannah River Company

Savannah River Site

Aiken, South Carolina 29808

C. A. Langton

This paper was prepared in connection with work done under the above contract number with the U. S. Department of Energy. By acceptance of this paper, the publisher and/or recipient acknowledges the U. S. Government's right to retain a nonexclusive, royalty-free license in and to any copyright covering this paper, along with the right to reproduce and to authorize others to reproduce all or part of the copyrighted paper. 


\section{DISCLAIMER}

Portions of this document may be illegible electronic image products. Images are produced from the best available original document. 


\section{SLUDGE DISPLACEMENT VERIFICATION FOR REDUCING GROUT REPORT (U)}

T. B. Caldwell

High Level Wăste'Management Division

and

C. A. Langton

Savannah River Technology Center

April 10, 1997

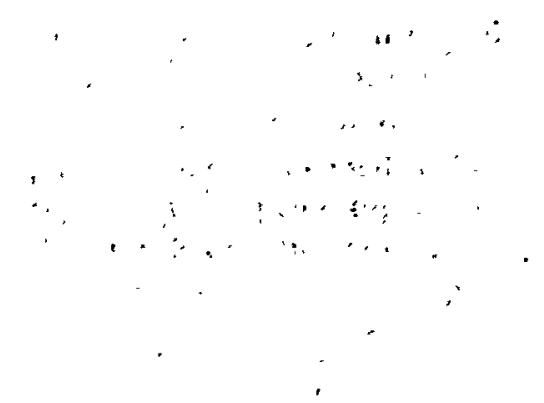

Prepared for the U. S. Department of Energy under Contract DE-AC09-96SR18500 
This document was prepared in conjunction with work accomplished under Contract No. DE-AC09-96SR18500 with the U. S. Department of Energy.

\section{DISCLAIMER}

This report was prepared as an account of work sponsored by an agency of the United States Government. Neither the United States Government nor any agency thereof, nor any of their employees, makes any warranty, express or implied, or assumes any legal liability or responsibility for the accuracy, completeness, or usefulness of any information, apparatus, product or process disclosed, or represents that its use would not infringe privately owned rights. Reference herein to any specific commercial product, process or service by trade name, trademark, manufacturer, or otherwise does not necessarily constitute or imply its endorsement, recommendation, or favoring by the United States Government or any agency thereof. The views and opinions of authors expressed herein do not necessarily state or reflect those of the United States Government or any agency thereof.

This report has been reproduced directly from the best available copy.

Available for sale to the public, in paper, from: U.S. Department of Commerce, National Technical Information Service, 5285 Port Royal Road, Springfield, VA 22161, phone: (800) 553-6847, fax: (703) 605-6900

email: orders@ntis.fedworld.gov

online ordering: http://www.ntis.gov/help/index.asp

Available electronically at http://www.osti.gov/bridge

Available for a processing fee to U.S. Department of Energy and its contractors, in paper, from: U.S. Department of Energy, Office of Scientific and Technical Information, P.O. Box 62, Oak Ridge, TN 37831-0062,

phone: (865)576-8401,

fax: (865)576-5728

email: $\underline{\text { reports@ adonis.osti.gov }}$ 
HIGH LEVEL WASTE ENGINEERING

TANK FARM PROJECT ENGINEERING

Sludge Displacement Verification

For Reducing Grout Report

By

T. B. Caldwell

And

C. A. Langton

Issued: April 9, 1997

APPROVALS

T. B. Caldwell, Author, HLWE

C. A. Langton, Author, HLWE

B. A. Martin, Technical Reviewer, HLWE

B. T. Butcher, Manager, Waste Disposal, SRTC

E. Saldivar, Manager, Waste Removal Group

T. M. Monahon, Manager, HLWE
WSRC-TR-97-0101

REVISION: 0

Keywords:

Tank closure

Grout

Sludge

Retention: Permanent

Classification: $\mathbf{U}$

Does Not Contain UCNI

ADC/RO

Date:

Date:

Date:

Date:

Date:

Date: 
Report Revision Number: .

Report Number: WSRC-TR-97-0101

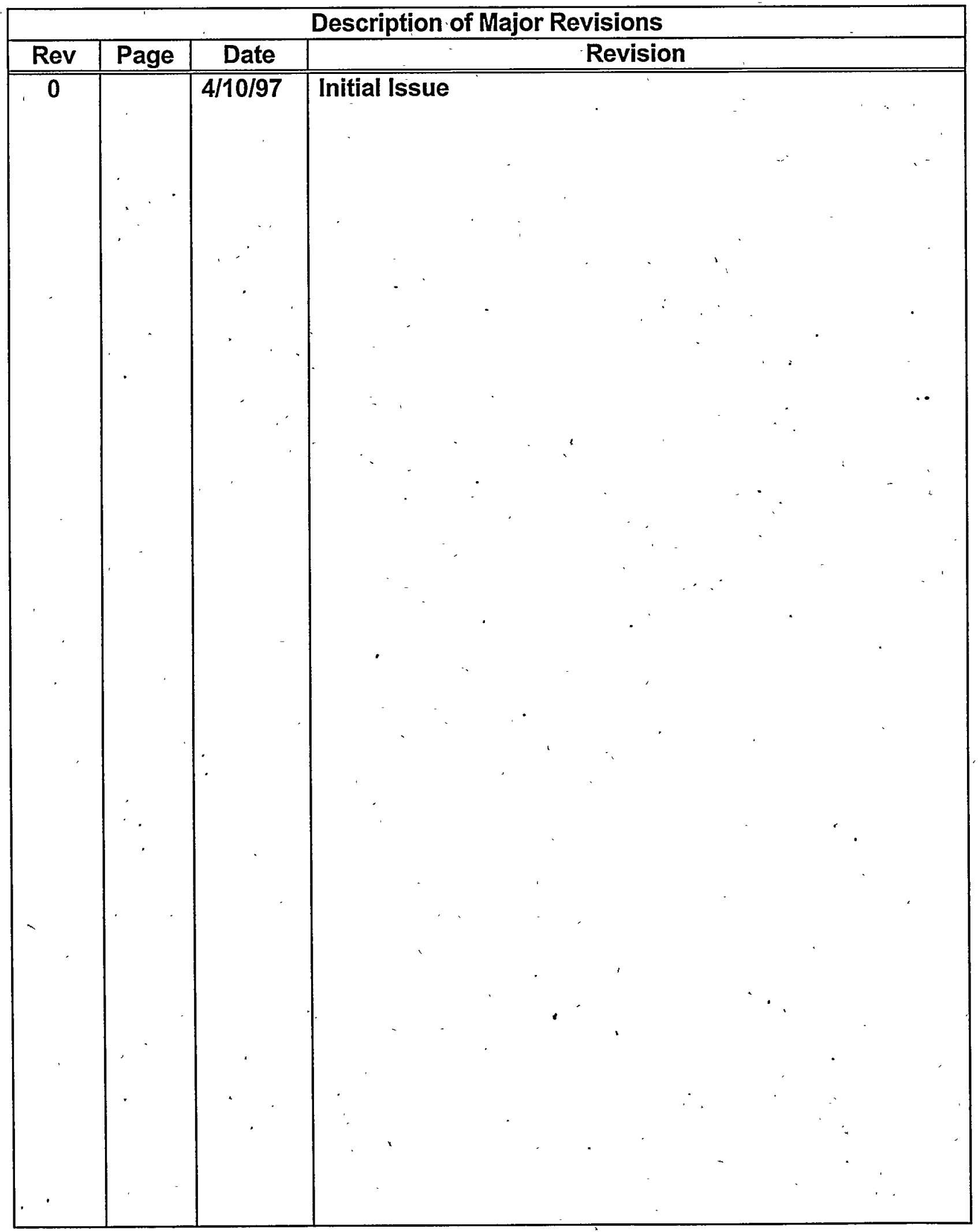


WSRC-TR-97-0101

Revision 0

Page 2

\section{TABLE OF CONTENTS}

Section

I. EXECUTIVE SUMMARY

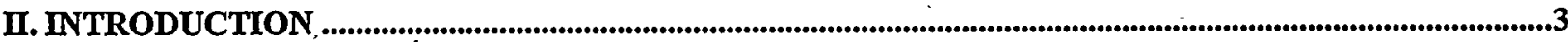

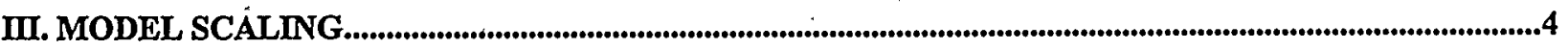

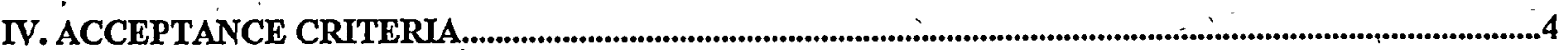

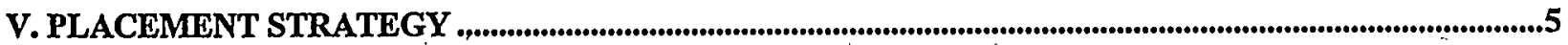

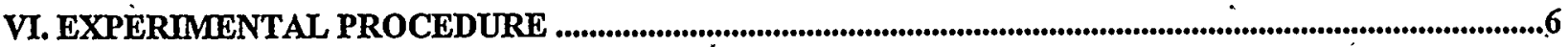

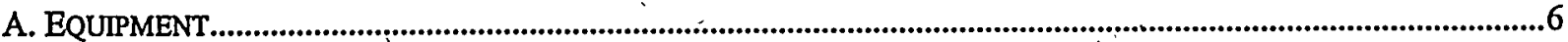

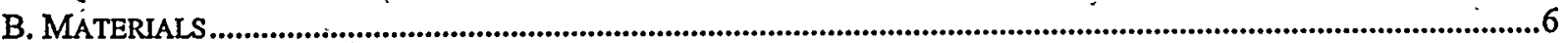

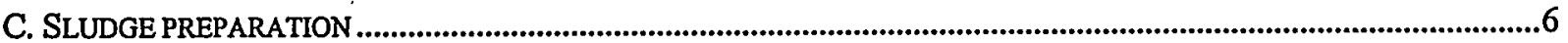

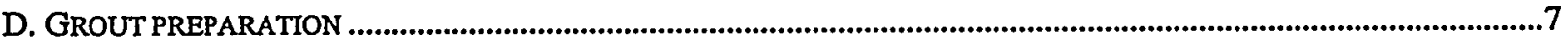

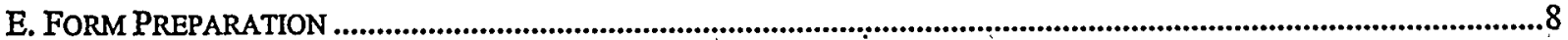

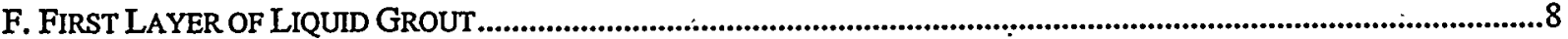

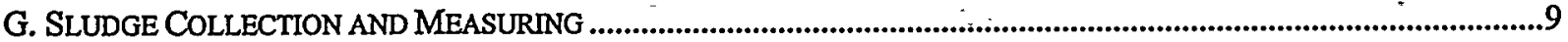

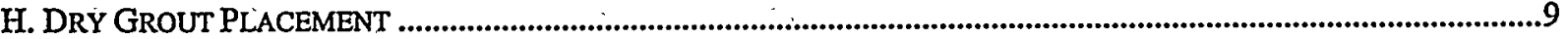

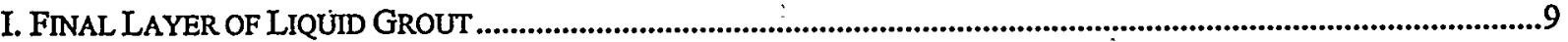

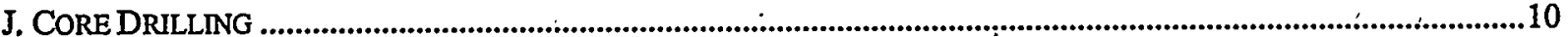

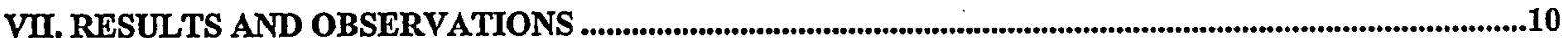

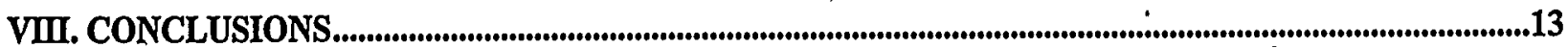

IX. REFERENCES

$\begin{array}{ll}\text { APPENDICES } & \\ \text { APPENDIX A } & \text { TANK CLOSURE TEST PLAN, SLUDGE DISPLACEMENT } \\ & \text { VERIFICATION FOR REDUCING GROUT } \\ \text { APPENDIX B } & \text { FLOW CONE DESIGN SPECIFICATION } \\ \text { APPENDIX C } & \text { SLUDGE AND GROUT MAP } \\ \text { APPENDIX D } & \text { FINAL GROUT FLOW PATTERN } \\ \text { APPENDIX E } & \text { PHOTOGRAPHS. }\end{array}$




\section{Executive Summary}

To support the closure of HLW tanks at SRS, a reducing grout was developed that is formulated to reduce the mobility of radionuclides left in each tank. During non-radioactive flow tests of the grout, it was discovered that, in addition to its desired properties, the grout has the ability to move residual waste a considerable distance across the tank floor.

Projections are that if the grout were poured through the center riser of the tank, most of the residual sludge in the tank would end up on top of the reducing grout within a few feet of the tank wall. This is an undesirable location for the contaminants after closure. A more desirable location for the contaminants would be to have the contaminants spread across the tank floor and completely incorporated in the grout layer.

On March 19-20, 1997, a grout placement incorporation test was successfully conducted in a 24-foot diameter simulated tank at the Central Shops Facility. It was successfully shown that the distribution of sludge can be improved by pouring the grout into the tank in multiple locations and by pouring the grout in two lifts with an addition of a dry grout mixture between lifts. Grout was alternately poured through six opposing locations then center poured for a total of seven simulating the location of the seven risers in Tanks 17 and 20. After the first lift, dry grout was distributed on top of the lift, and then a second lift was poured the next day. The simulated sludge was effectively incorporated within the grout layer (30\% incorporation on the first lift, $65 \%$ incorporation within the dry grout, and $5 \%$ in the second lift)

This method has proven to be a successful method of grout placement incorporation for tank closure.

\section{Introduction}

-The reducing grout was designed and tested by Construction Technology Laboratories, Inc. (CTL) located in Skokie, Illinois. ${ }^{1}$ During pilot testing at CTL, it was discovered much of the residual sludge was displaced by the flowing grout and eventually floated on top of the grout. If the grout were to be poured into the tank from a single centrally located point as originally planned in the Tank 20 and 17 Closure Module ${ }^{2,3}$, the sludge would flow to the outside tank edges as the grout advances towards the walls. This would result in a less than optimal closure condition since the residual waste would be physically closer to the unprotected outside edges where it could be exposed to oxidizing acidic groundwater rather than the desired reducing alkaline conditions produced by the grout.

An alternate proposal was to pour through the six outer risers pushing the sludge to the center with a final center pour to raise and evenly spread the sludge on top of the previous pours. Therefore, it was

\footnotetext{
' Final Report for Westinghouse Savannah River Company and United States Department of Energy, Aiken, SC, Development of Reducing Grout for Closure of Savannah River Site Tank \#20, October, 1996, Construction Technology Laboratories (CTL).

${ }^{2}$ Page 5-4, Industrial Wastewater Closure Module for the High-Level Waste Tank 17 System, U.S. Department of Energy, Savannah River Site, Draft

${ }^{3}$ Page 5-4, Industrial Wastewater Closure Module for the High-Level Waste Tank 20 System, U.S. Department of Energy, Savannah River Site. 
proposed that this multiple grout pour proposal be tested on a small scale. Pour locations along the perimeter as well as the center of the tank were employed to deliver grout to simulate riser locations. It was anticipated that the grout would incorporate much of the simulated sludge (referred to as sludge in this report) in the folds where the grout masses meet and that any remaining sludge would be more evenly distributed along the surface of the first grout layer. A dry grout dressing was added to the surface of the first layer of grout to absorb loose sludge. After the dry material set (reacted with the water in the sludge), the second layer of the reducing grout was placed on the set dry grout to form a "sandwich" configuration encasement for containing the sludge.

The primary purpose of this experiment is to estimate and document the quantity of simulated sludge that is incorporated by the first layer of grout and the quantity of simulated sludge that moves as a loose form towards the top of the test form by this grout placement method. This report also documents observations concerning sludge movement patterns during a multiple entry point pour regime.

\section{Model Scaling}

A scaled down version of the full sized 85-foot diameter waste tank was used to simulate the placement strategy of the reducing grout: A size reduction requires that volumes and flow rates be adjusted to simulate full scale conditions. The grout has been observed to displace any flowable sludge as it is introduced into a form. The grout consistency will be similar to that used in the tank to achieve a similar elevation profile.

The test tank was roughly one fourth the diameter of the actual tank. Therefore volumes and fill times needed to be scaled down appropriately: ${ }^{4}$

Table 1. Modeling Scale Down Parameters

\begin{tabular}{l|c|c|c}
\multicolumn{1}{c|}{ Parameters } & Scale Formula & Actual & Test \\
\hline \hline Viscosity (flow cone - seconds) & $\mu_{\mathrm{M}}=\mu_{\mathrm{A}}$ & $2-5$ & $2-5$ \\
\hline Fill Time (hours) & $\mathrm{t}_{\mathrm{M}}=1 / 4 \mathrm{t}_{\mathrm{A}}$ & 6.25 & 1.56 \\
\hline Volume (cubic yards) & $\mathrm{V}_{\mathrm{M}}=\mathrm{V}_{\mathrm{A}} / 64$ & 250 & $>3.91$ \\
\hline Fill Rate (cubic yards per hour) & $\mathrm{Q}_{\mathrm{M}}=\mathrm{Q}_{\mathrm{A}} / 16$ & 40 & 2.50 \\
\hline
\end{tabular}

A rate $2.50 \mathrm{yd}^{3} / \mathrm{hr}$ is equivalent to $8.4 \mathrm{gpm}$, or more practically $8-10 \mathrm{gpm}$, however, limitations in the grout delivery system prevented the grout from being delivered at that rate: The sludge in the actual . tanks are assumed to be one inch. Therefore, the sludge was placed at a depth of approximately $1 / 4$ to $1 / 3$ inches. This corresponded to 71-94 gallons in the test tank.

\section{Acceptance Criteria}

A successful test of the grout placement strategy and techniques is demonstrated by the following:

${ }^{4}$ [Reference deleted during review] 
WSRC-TR-97-0101

Revision 0

Page 5.

1. The grout does not move the sludge into a single area configuration, i.e. the grout is able to spread the sludge in a diffused pattern.

2. There is a measurable quantity of sludge incorporation in the first layer of grout.

3. The sludge can be "fixed," or held immobile, during the final grout layer so that no sludge floats above the final grout layer thereby yielding complete incorporation of the sludge in the grout system.

The test plan, Appendix A, did not include the acceptance criteria, however the design of the method and the verification of data was intended to achieve the aforementioned results.

\section{Placement Strategy}

Observations from the CTL test conducted on March 5, 1997 revealed large amounts of sludge being displaced by the grout as it was being placed in the form. A recommendation was made to control the sludge movement. This included using a multiple point pour to evenly distribute the grout along the tank bottom ${ }^{5}$ and using a dry grout material to absorb and react with the water in the loose sludge.

In the specific configuration of the Type IV tank, perimeter risers are denoted sequentially as location no.'s 1 through 6. (Refer to Figure 1. a location map.) Approximately $1 / 9$ of the material would be poured at location no. 1 , then $1 / 9$ at location no. 3 , then $1 / 9$ at location no. 5 , then $1 / 9$ at 2 , then 4 , and then 6 . Then the center riser would get filled with the remaining $3 / 9$ of the material.

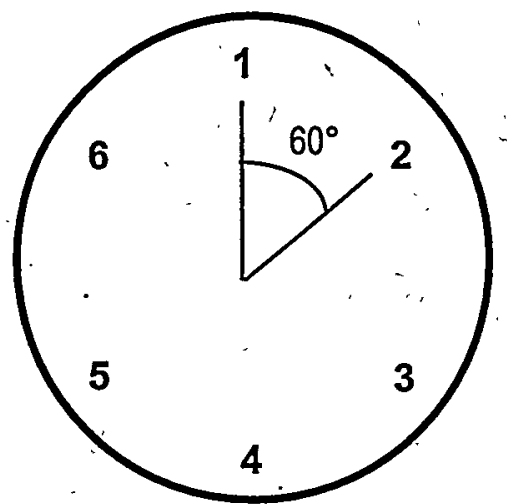

Figure 1. Grout Pour Orientation

A dry grout material would be placed over the first layer of grout to effectively cover any loose, wet sludge material and subsequently react with the water to form a solid mass of grout and sludge. After setting of the dry grout mix, a final delivery of grout would be introduced at the center location to cover the first layer and the hardened dry mix.

${ }^{5}$ M. C. Roco to R. Campbell, "Closure of Tank \#20 in the High Level Waste Tank Farm Facility (ABB94260S)," March 8, 1997. 
WSRC-TR-9.7-0101

Revision 0

Page 6

\section{Experimental Procedure}

\section{A. Equipment}

- 24 foot diameter test form fabricated from a circular above-ground swimming pool, with a wall height of 4 feet capable of withstanding a 4 foot hydraulic head, lined with 20 mil ( 0.020 inch) polyethylene plastic.

- Grout delivery system which included a hopper, a piston pump capable of variable . flow rates, piping, flexible hoses, and a movable personnel lift.

- Flow cone constructed to specifications shown in Appendix B.

- Core Drill

- Squeegees with extended handles

- Shop vacuum cleaner

- Camera

- Video recording equipment

- Tape Measure

- Drum mixer

- Stopwatch

B. Materials

- 12 cubic yards of grout mix no. 3TK-X-S-0-R per specification C-SPP-F-000386

- 71-94 gallons of SRS DWPF cold run sludge simulant spiked with sodium oxalate, sodium carbonate, sodium hydroxide, copper sulfates, and sodium sulfate.

- Dry grout material mix which contains the following: sand $1625 \mathrm{lbs}$, Type V cement $1353 \mathrm{lbs}$, and slag $209 \mathrm{lbs}$.

\section{Sludge preparation}

The simulated sludge was spiked with copper which was intended to serve as a "fingerprint"constituent for the sludge. Copper is not present in significant quantities in the grout. Nickel which was already present in the sludge was also used as a "fingerprint" element. The simulated sludge was prepared according to the following method:

- Approximately 150 gallons of simulated sludge was obtained from the TNX supply of DWPF simulant.

- The following chemicals were added to adjust this starting material to the waste tank chemistry.

\begin{tabular}{l|c}
\multicolumn{1}{c|}{ Chemical } & $\mathrm{kg} / 10$ gal of simulated sludge \\
\hline $\mathrm{NaOH}$ & 0.236 \\
$\mathrm{Na}_{2} \mathrm{SO}_{4}$ & 1.627 \\
$\mathrm{Na}_{2} \mathrm{C}_{2} \mathrm{O}_{4}$ & 2.176
\end{tabular}

${ }^{6}$ Tank Closure - Furnishing and Delivery of Tank Fill Materials and Reducing Grout (U), C-SPP-F-00038, Savannah River Site, Revision 2.

${ }^{7}$ P. D. d'Entremont and J. R. Hester, Characterization of Tank 20 Residual Waste, Revision 0, WSRC-TR-96-0267. 
WSRC-TR-97-0101

Revision 0

Page 7

\begin{tabular}{l|c}
\multicolumn{1}{c|}{ Chemical } & $\mathrm{kg} / 10$ gal of simulated sludge \\
\hline $\mathrm{Na}_{2} \mathrm{CO}_{3}-\mathrm{H}_{2} \mathrm{O}$ & 8.609 \\
$\mathrm{CuSO}_{4}-5 \mathrm{H}_{2} \mathrm{O}$ & 0.944
\end{tabular}

Chemicals were added individually as the sludge was continuously mixed for up to 5 hours. The sludge was mixed for at least 45 minutes after the final addition.

On March 19, 1997, two drums of the prepared sludge were mixed for at least one and a half hours at the test site. Approximately 81 gallons of simulated sludge were pumped into the test form and evenly spread across the entire bottom of the tank.

\section{Grout preparation}

About 5.5 cubic yards of reducing grout were prepared by G. L. Throope on March 17, 1997 after calibration of the raw materials and admixture metering equipment. Flow measurements made on the initial material prepared in the auger mixer had flow cone measurements of 2 to 4 seconds. Refer to Appendix B for the test method. Based on these results, the amount of high range water reducer was reduced (HRWR) by 50 volume \%. This had no effect on the flow cone measurements. Examination of the material exiting the auger indicated that the slurry was lumpy. The auger angle and rotation speed were both increased to the maximum amount. Better mixing was achieved.

The grout was discharged into a pump hopper and pumped about 200 feet to a concrete truck. The flowability of the material as it was discharged.into the truck was much thicker (not flowable) compared to the grout exiting the auger. This indicates that although the particles appeared wetted upon exiting the auger, they were dispersed more during pumping.-

Consequently it was necessary to add 2 additional gallons of HRWR to the concrete truck prior to leaving the mixing site at 1410 hours. At the test site, it was also necessary to add 4 more gallons of HRWR between 1430 and 1445 hours to the mix was sufficiently modified to give the 6 second flow cone measurement specified for this test. This was considered the calibration run for the experiment.

About 6 cubic yards of reducing grout were prepared by G. L. Throope on March 19, 1997 for the test pour in the test form. The amount of HRWR was increased in this batch of reducing grout to $125 \%$ of the design amount. This material was again pumped to a concrete truck and driven to the test site. The truck left the batching site at 1050 hours. The flow measured on the grout collected at the auger was 4 seconds. However by the time the material reached the test site at about 1110 hours, the grout was too thick for a flow measurement. Additional HRWR and retarder were obtained from the batching plant. At 1210 hours; 4 gallons of HRWR were added. At 1217, 2 more gallons were added to achieve a flow of 4 seconds. At 1125 hours 2 gallons of retarder and 3 gallons of HRWR were added to maintain flow and delay setting so that the pour could be completed. The resulting flow was 4 seconds. (It should be noted that all of the admixtures added after the auger mixing were diluted with water by $50 \%$ since this is the material that was immediately available from Throope.)

An additional 6 cubic yards of reducing grout were prepared by G. L. Throope on March 20, 1997 , to support the final grout layer. Parameter's were adjusted as described herein. The reducing grout prepared for this test had a fresh unit weight of $134 \mathrm{lbs} / \mathrm{ft}^{3}$. Flow cone 
measurements, sampling and property measurements were performed by Raytheon concrete technicians in the field and in the on-site concrete test laboratory.

\section{E. Form Preparation}

A 24-foot diameter above-ground residential-grade swimming pool was constructed at the 717-N Central Shops facility to be used as the test form. The form was placed on a flat and level concrete pad which was covered by a roof. The liner was made of $20 \mathrm{mil}(0.020$ inch $)$ thick polyethylene plastic and was drawn tight to the walls by evacuating the air between the sides and the liner using a shop vacuum cleaner. The liner was then manually smoothed to reduce any wrinkles. Any irregularities on the form floor did not exceed 1 inch in vertical height. Complete unrestricted access was available from above the form. The liner was verified to be resistant to the sludge using a simple 24 hour exposure test. The outside wall of the pools were marked at locations $60^{\circ}$ apart to signify the perimeter pour locations.

The mixed sludge was poured in the form and spreading evenly over the bottom using squeegees. The initial volume of sludge was 81.7 gallons as measured dimensionally in the 55-gallon storage drums. The final-depth of the sludge ranged from 0.125 inch to 0.375 inch with the floor completely covered with the sludge simulant. While waiting for other preparations, some drying of the sludge occurred forming a fragile thin skin of dried sludge and salts. The drying was evident by a lightening of the normally dark brown color of sludge simulant with salt crystals of carbonate and oxalate forming on the surface. The sludge was easily re-wetted using a squeegee. The volume reduction effects by this drying were considered minor and assumed to be negligible.

\section{F. First Layer of Liquid Grout}

The grout delivery system was setup using a grout pumping hopper. The delivery mixer truck . poured the grout into the hopper where the grout was then gravity-fed into a diesel driven reciprocating piston pump calibrated to its lowest stable setting. The pump flow rate was verified to have a flow rate of approximately $35-40 \mathrm{gpm}$. Note that this was in excess of the modeled rate so an overall averaging approximation was considered as specified in the test plan. The pump was continuously manned to ensure it was cycling at the preset limit. The pump discharge was delivered through a flexible two-inch diameter (ID) hose. However, because of availability problems with obtaining a long hose, a three-inch diameter PVC rigid pipe was used to deliver the grout to the distant pour locations. When not being delivered to the form, the grout was recirculated in the hopper to ensure continuous agitation.

For the first layer, grout was introduced at each location shown in Sketch No. 1 of Appendix A. Grout was dropped at the perimeter locations (no.'s 1 through 6) at a 1-2 foot distance from the edge of the form. Typically, a grout "patty" was poured and allowed to spread to approximately $1 / 2$ to $3 / 4$ of the distance to the adjacent pour locations. Grout was then poured at the center of the form (location no. 7). The drop height did not exceed 3 feet. Table 2 reflects the sequence and pour times for each location. 
Table 2. First Grout Layer Pour Times and Sequence

\begin{tabular}{c|c|c|c} 
Sequence & Pour Location & $\begin{array}{c}\text { Fill Time } \\
\text { (minutes) }\end{array}$ & $\begin{array}{c}\text { Estimated Volume } \\
\text { (gallons) }\end{array}$ \\
\hline \hline $\mathbf{1}$ & 1 & 3.5 & $122-140$ \\
\hline 2 & 3 & 2.1 & $74-84$ \\
\hline 3 & 5 & 5.7 & $200-228$ \\
\hline 4 & 2 & 3.3 & $116-132$ \\
\hline 5 & 4 & 2.8 & $98-112$ \\
\hline 6 & 6 & 1.3 & $46-52$ \\
\hline 7 & 7 & 7.4 & $260-296$ \\
\hline
\end{tabular}

The total amount of grout poured was between 916-1044 gallons (4.53-5.17 cubic yards) delivered over 70.1 minutes to yield an overall average introduction rate of $14 \mathrm{gpm}$ flow rate. The form was then covered with clear polyethylene sheeting and sealed with duct tape to limit the amount of evaporation from the sludge. The grout was allowed to set overnight.

\section{G. Sludge Collection, and Measuring}

The sheeting was removed and any condensed moisture collected under the sheet was shaken off and allowed to fall.into the form. The loose sludge was collected using a shovel, broom, and a wet/dry shop vacuum cleaner and the volume of the collected material was measured. Care was taken to gather all loose (not affixed) sludge to the extent practical. The total volume of collected sludge was 57.87 gallons. The sludge was then thoroughly mixed for at least 15 minutes in the collection drums using a drum mixer. The sludge was then poured back into the forms in approximately the same configuration as before.

\section{H. Dry Grout Placement}

About 1000 lbs of dry grout mix was then spread manually in an even fashion over the wet sludge. The dry mix was spread over sludge using various application techniques. The mix was hand sprinkled, shoveled, or tossed onto the sludge. All of these methods yielded similar results. The dry mix was added until the sludge was either completely covered with the mix or until the sludge and grout mixture had the consistency of damp soil. This matrix was allowed to set for 3 hours.

\section{Final Layer of Liquid Grout}

A final layer of grout was poured into the center location (no. 7) at a drop height not exceeding 3 feet. The flow rate was again between $35-40 \mathrm{gpm}$. A total of 5.8-6.7 cubic yards was placed in 34 minutes to cover the first layer and dry grout matrix. The entire grout system was allowed to cure for a minimum of 60 hours. 


\section{J. Core Drilling}

Samples of the material placed in the test form were obtained by wet coring. Bechtel Construction personnel cored 8 locations using a 3 inch barrel. Cores were labeled and photographed by SRTC technicians. Cores were cut length wise with a masonry saw by Bechtel personnel. The cores were then cut into sections representing layer I, dry grouted sludge (layer II), and grout layer III. No water was used in the cutting process.

One half of each layer was retained for visual characterization. The other parts were labeled and packaged for shipment to General Engineering Laboratories for nickel and copper analyses.

\section{Results and Observations}

Each patty of grout spread in similar fashion, however the actual pattern and shape was unique for each pour location. The grout displayed non-Newtonian thixotropic flow behavior, as anticipated from previous tests at CTL. ${ }^{8}$ Each grout patty mounded to a low profile dome as the grout was being poured. The grout did not spread outward evenly and uniformly due its thixotropic properties. The grout masses appeared to take turns in flowing in different directions creating irregular shaped masses. The criteria for placement of each patty was to ensure that outer edges of the grout mass flowed to at least one-half to three-quarters of the distance to the adjacent pour points. However, some patties, such as the one poured at location no. 3 , were reluctant to spread along the edge of the tank in the direction of the adjacent pour locations. This is the reason that the grout pour at this location had a larger than average pour time.

As expected, the grout displaced the sludge and pushed it away from the pour point. Eventually, all of the perimeter patties intersected forming a ring of grout along the perimeter of the form (except for approximately $1 / 2 \%$ of the total area which is discussed later). The loose sludge flowed to low elevations and collected in the center of the form. The patty poured at the center location pushed the sludge away from the center and back towards the form perimeter. The center patty eventually intersected with the six perimeter patties and effectively lifted the loose sludge off of the form floor. A ring of sludge formed in the valleys of first grout layer. The ring was located approximately midway between the form wall and the form center with a width of approximately two feet. Some of the sludge also migrated to the form wall to develop six "spokes." Refer to Appendix C for a map of the final sludge configuration. The map was developed by estimating the shape and area from photographs taken of the pours. Approximately $34 \%$ of the flat surface area is taken up the sludge.

Approximately $70-75 \%$ of the sludge was collected into drums using shovels, brooms, and a wet/dry vacuum cleaner. The remaining sludge appeared either trapped at the grout patty intersections or permanently fixed to the surface of the hardened grout. This sludge was dried and could not be removed without also removing a portion of the grout. Therefore, approximately $25-30 \%$ of the sludge is considered incorporated with the first layer of grout. Furthermore, it was noticed that there were two small zones of incomplete intersection of the grout patties, but this accounted for less than $1 / 2 \%$ of the total bottom surface area. Refer to Appendix $C$ for these locations. The collected sludge was remixed to the same apparent consistency as at the beginning of the procedure to facilitate easy pouring. This mixing had no effect on the outcome of the experiment. The sludge was reintroduced to the form where

${ }^{8}$ Page 2, CTL 
it was allowed to flow to the lower elevations of the grout mat thereby forming a spoked ring pattern similar to the original configuration.

The dry grout material was manually spread over the loose sludge. The dry grout immediately absorbed the excess moisture and sunk through the sludge. Enough material was spread to completely cover the loose sludge. The sludge/grout mixture in some areas had the appearance of damp soil. After three hours, the mixture had set sufficiently to walk on without substantial subsidence.

The second grout pour was made at the center location. The rheological characteristics were again thixotropic exhibiting noticeable "stick and slip" flow behavior. The grout would ebb in one direction and then another. At first, the direction of the ebbs appeared to be random, however within 10 minutes the flow directions alternated in a counter-clockwise spiral (perhaps due to the Coriolis effect.) Refer to Appendix D for a schematic of these patterns. The grout flowed over the dry material easily without hesitation or substantial mounding. Furthermore, the 6-inch tall mounds placed in the form did not seem to have an effect on the flow pattern and the mounds were eventually engulfed by the grout. Very small amounts of the loose sludge trickled to the surface of the dry material in liquid form as the grout advanced over some areas. However, the loose sludge ultimately folded into the grout flows. The final layer did not completely cover the first layer. It was estimated that 1 to 2 more yards in addition to the original 6 yards would have been sufficient to completely cover the first layer of grout and dry grout/sludge mix. After a minimum of 60 hours of cure time, the grout had completely set. Small shrinkage cracks had developed over the surface of the final grout with the largest cracks having a width between $0.025-0.050$ inches. The compressive strength of this grout after curing 14 days was $6665+/-$ 5 psi.

Eight (8) 3-inch diameter core samples were taken at judgmentally selected areas in accordance with the sampling plan outlined in Appendix A. The cores revealed that the sludge was sandwiched between the grout layers and that the sludge had reacted with the dry grout material yielding a hardened mass. Three distinct layers exist for these cores.

I. The first layer was formed when pouring the first grout patties. Sludge staining was.found on the bottom of seven cores. One core was found to have a $1 \mathrm{~cm}$ thick lens of sludge attached to the bottom. Some of the samples revealed that sludge coated the top surface.

II. The second layer is predominately a sludge and grout mixture formed when the dry grout was applied. This layer, though hardened, generally had weak adhesion to the first and third layer. Some cores did not have this layer.

III. The third layer was formed during the final grout pour.

The core locations are shown in Appendix C. Refer to Appendix E for photographs of each core.

The copper and nickel tracer elements spiked in the sludge simulant were analyzed for each core at different elevations. This provides a method in which to estimate the amount of sludge combined in the grout for each layer. Pure sludge had a nickel concentration of $3420 \mathrm{mg} / \mathrm{kg}$ and the copper concentration was $4680 \mathrm{mg} / \mathrm{kg}$. Sludge concentration in the grout was determined by dividing the tracer element concentrations by the pure sludge concentrations. Table 3 summarizes the results from this evaluation. 
WSRC-TR-97-0101

Revision 0

Page 12

Table 3. Analysis of Core Samples

\begin{tabular}{|c|c|c|c|c|c|}
\hline Core No. & Layer & $\begin{array}{l}\text { Nickel Conc. } \\
(\mathrm{mg} / \mathrm{kg})\end{array}$ & $\begin{array}{c}\text { Copper Conc. } \\
\text { (mg/kg) }\end{array}$ & $\begin{array}{c}\text { 'Sludge Conc } \\
\text { Ni Based } \\
\text { (wt\%) }\end{array}$ & $\begin{array}{c}\text { Sludge Conc } \\
\text { Cu Based } \\
(w t \%)\end{array}$ \\
\hline \multirow[t]{2}{*}{1} & $\mathrm{I}$ & 128 & 184 & $: 3.7$ & 3.9 \\
\hline & III & 15 & 4 & 0.4 & 0.1 \\
\hline \multirow[t]{2}{*}{2} & $\bar{I}$ & 25 & 36 & 0.7 & 0.8 \\
\hline & mII & 8 & 13 & 0.2 & 0.3 \\
\hline \multirow[t]{3}{*}{3} & I & 224 & 316 & 6.5 & 6.8 \\
\hline & II & 1340 & 1790 & 39.2 & 38.2 \\
\hline & III & . 14 & $24 \div$ & 0.4 & 0.5 \\
\hline \multirow[t]{3}{*}{4} & I & 268 & 396 & 7.8 & 8.5 \\
\hline & II & 777 & 1090 & 22.7 & 23.3 \\
\hline & III & 5 & 11 & 0.1 & 0.2 \\
\hline \multirow[t]{3}{*}{7} & $\mathrm{I}$ & 379 & 526 & 11.1 & 11.2 \\
\hline & II & 909 & 1220 & 26.6 & 26.1 \\
\hline & III & 3 & 8 & 0.1 & 0.2 \\
\hline \multirow[t]{3}{*}{8} & I & 56 & 77 & 1.6 & 1.6 \\
\hline & II & 698 & 926 & 20.4 & 19.8 \\
\hline & III & 34 & 10 & 1.0 & 0.2 \\
\hline
\end{tabular}

Averaging all of the concentrations (nickel and copper based) for each layer yields the following results:

Table 4. Sludge Concentration by Layer

\begin{tabular}{c|c|c} 
Layer & $\begin{array}{c}\text { Sludge } \\
\text { Concentration (wt\%) }\end{array}$ & $\begin{array}{c}\text { Standard } \\
\text { Deviation }\end{array}$ \\
\hline \hline I & 5.365 & 3.828 \\
\hline II & 27.035 & 7.592 \\
\hline III & 0.317 & 0.253 \\
\hline
\end{tabular}

Between $122-140 \mathrm{ft}^{3}$ of grout was placed in the first layer. With a density of $134 \mathrm{lbs} / \mathrm{ft}^{3}$, approximately $16,300-18,800 \mathrm{lbs}$ of material was placed. About 34\% of the surface of the first layer was covered with sludge based on a mapping analysis. Refer to Appendix C. Assuming that only the grout covered with sludge was affected by sludge, then $5500-6400 \mathrm{lbs}$ of grout has the sludge in concentrations assumed in Table.4. Considering sampling standard deviation, the grout+sludge weight in layer I ranges from 5600 - $7000 \mathrm{lbs}$ based on tracer sampling results. Further evaluation reveals that the range of sludge in this layer could be between $85-640 \mathrm{lbs}$ with a mean of 360 .lbs. The sludge that remained in layer I was measured to be 23.8 gallons which correlates to a weight of $298 \mathrm{lbs}$ (density of sludge simulant $=93.6$ $\mathrm{lbs} / \mathrm{ft}^{3}$ ). Therefore the sampling for sludge for layer I correlates to the amount of sludge extracted for direct measurement:

About $1000 \mathrm{lbs}$ of dry material was placed on the wet sludge layer and allowed to harden. Based on sampling results for layer II, the grout+sludge weight ranges from $1200-1500 \mathrm{lbs}$. Therefore, the sludge weight estimate is evaluated to be $230-.520 \mathrm{lbs}$. with a mean of $380 \mathrm{lbs}$ assuming information based 
solely from sample data. If the weight of sludge in layer III is discounted, then the actual sludge weight in layer II is $720 \mathrm{lbs}$.

The third layer has minute amounts of sludge present. Assuming that $34 \%$ of the total grout poured is affected (based on area analysis), then the total sludge in this layer ranges 5-50 lbs.

\section{Conclusions}

The method of using a multiple pour strategy was effective in incorporating a loose sludge residual. A little less than one third of the sludge becomes tightly affixed to the first layer of grout and the remaining loose sludge is rendered immobile by a subsequent application of dry grout material. These first two layers worked together to immobilize over $95 \%$ of the sludge. The remaining sludge is further trapped by the final layer of grout with no further vertical movement of the sludge. The sludge is essentially sandwiched between two reducing grout layers with a reducing grout matrix intrinsic with the sandwiched sludge.

The grout can be used to move the sludge to desirable locations within the tank and can therefore be used to configure the sludge in a final sandwiched configuration. However the grout, though fluid, possesses strong thixotropic behavior. This causes the grout to have a degree of unpredictability in the final pour pattern. This explains why each patty in layer I was unique in shape. Such behavior can be expected in actual tank closure operations. It is therefore concluded that the method piloted by this experiment, if reproduced in the field, will yield similar results.

\section{References}

1. Bechtel Savannah River Inc., Tank Closure - Furnishing and Delivery of Tank Fill Materials and Reducing Grout (U), C-SPP-F-00038, Savannah River Site, Revision 2.

2. Construction Technology Laboratories, Final Report for Westinghouse Savannah River Company and United States Department of Energy, Aiken, SC, Development of Reducing Grout for Closure of Savannah River Site Tank \#20, October, 1996, Under WSRC Subcontract No. AB84977S.

3. d'Entremont, P. D., and Hester, J. R, Characterization of Tank 20 Residual Waste, WSRC-TR96-0267, Révision 0.

4. M. C. Roco to R. Campbell, "Closure of Tank \#20 in the High Level Waste Tank Farm Facility (AB94260S)," March 8, 1997.

5. U.S. Department of Energy, Industrial Wastewater Closure Module for the High-Level Waste Tank 17 System, Savannah River Site, Draft

6. U.S. Department of Energy, Industrial Wastewater Closure Module for the High-Level Waste Tank 20 System, Savannah River Site. 
WSRC-TR-97-0101

Revision 0'

Appendix A

Page 14

\section{APPENDIX A}

\section{TANK CLOSURE TEST PLAN SLUDGE DISPLACEMENT VERIFICATION FOR REDUCING GROUT}

Post dated copy is included as Appendix A. Original Revision 1 with hand marked up changes identical to the post dated copy was approved on March 19, 1997. Original Revision 1 is included in Document Control copy as HLW-HLE-97-0077 Revision 1. 
WSRC-TR-97-0101

Revision 0

Appendix A

Page 15

HLW-HLE-97-0077

Revision 1

\section{CORRECTED VERSION}

\section{HIGH LEVEL WASTE ENGINEERING DEPARTMENT \\ HIGH LEVEL WASTE MANAGEMENT DIVISION \\ SAVANNAH RIVER SITE}

\section{TANK CLOSURE TEST PLAN}

Sludge Displacement Verification

For

Reducing Grout

Print Name

$\underline{\text { Signature }}$

$\underline{\text { Date }}$

Prepared by:

$\underline{\text { Thomas B. Caldwell }}$

Concurrence:

HLWE Verifier

$\underline{\text { Jeff Newman }}$

HLW Regulatory

Sharon Marra

HLW Construction Matthew W. Thomas

SRTC Representative Christine A. Langton

HLWE Manager $\quad \underline{\text { T. M. Monahon }}$

Approval:

Tank Closure Mgr. $\quad \underline{\text { T. M. Monahon }}$

Post dated copy - original version signed on 3/19/97. No substantive changes made other than slight mathematical and editorial corrections. 
HLW-HLE-97-0077

Revision 1

Page 2

\subsection{INTRODUCTION}

Tanks $17 \mathrm{~F}$ and $20 \mathrm{~F}$ are being prepared for final closure. Grout with chemically reducing properties will be poured into each tank bottom to physically and chemically impede movement of any residual waste remaining in the tank. The grout pours will be followed up with successive lifts of controlled low strength material (CLSM) and standard grout, thereby filling void spaces in the tank.

The "reducing" grout was designed and tested by Construction Technology Laboratories, Inc. (CTL) located in Skokie, Illinois. During pilot testing at CTL, it was discovered much of the residual sludge was displaced by the flowing grout and eventually "floated" on top of the grout. If the grout were to be poured into the tank from a single centrally located point, the sludge would flow to the outside tank edges as the grout advances towards the walls. This would result in a less than optimal closure condition since the residual waste would be physically closer to the : unprotected outside edges where it could be exposed to oxidizing acidic groundwater rather than the desired reducing alkaline conditions produced by the grout.

Therefore, it is proposed that multiple grout pour locations be tested on a small scale. Pour locations along the perimeter as well as the center of the tank will be employed to deliver grout. It is anticipated that the grout will incorporate much of the sludge in the folds where the grout masses meet and that any remaining sludge would be more evenly distributed along the surface of the grout.

It is proposed to test a method of encapsulating loose sludge. The method is to add a dressing of dry reducing grout to the surface of the grout mat to absorb loose sludge after the first layer (placement or "lift"). After the dry material has set (reacted with the water in the sludge), the second layer of the reducing grout will be placed on the set dry grout to form a "sandwich" configuration encasement for containing the sludge.

\subsection{OBJECTIVES}

The purposes of this test are as follows:

2.1 Estimate and document the quantity of simulated sludge that is entrapped by the grout and the quantity of simulated sludge that moves as a loose form towards the top of the tank. See attached Sampling and Analysis Plan.

2.2 Document the sludge movement patterns during a multiple entry point pour.

2.3 Document the effectiveness of top dressing sludge simulant with dry grout.

2.4 Document the effectiveness of the grout cap on top of dressed sludge simulant.

\footnotetext{
* 'Dry grout top dressing specified for Tank 20 sludge contains the following ingredients and is batched by the Throop Plant: sand $1625 \mathrm{lbs}$, Type V cement $1353 \mathrm{lbs}$, and slag $209 \mathrm{lbs}$.
} 
HLW-HLE-97-0077

Revision 1

Page 3

\section{$3.0 \quad$ SCOPE}

A scaled down simulation is proposed to reflect the multiple grout pour entry points. There shall be one (1) form, known as the test tank, set up to perform the test case. Simulated waste sludge of a known and measured volume shall be placed on the bottom of the test tank to simulate the residual sludge. The grout will then be poured into the test tank on top of the simulated sludge by pouring from six (6) equidistant points located at the test tank perimeter and one (1) point in the center of the test tank.

The grout shall be poured in a predetermined pattern until approximately $31 / 2$ to 6 yards of grout material is placed. The grout will be allowed to harden sufficiently to permit removal of the residual sludge simulant. Any liquid sludge shall be removed from the test tank and the volume shall be measured. The sludge simulant will then be placed back into the test tank and then covered with a dry reducing grout treatment to immobilize the loose material. After dry grout has set (reacted with the water in the sludge), another $3 \frac{1}{2}$ to 6 yards of grout shall be poured.

Core samples shall be taken from the test tank to demonstrate the final layering of the grout and sludge (see attached Sampling and Analysis Plan).

\subsection{MODELING CONDITIONS}

The test tank shall be roughly $1 /$ th the diameter of the actual tank. Therefore the scaled parameters are as follows (note the test tank parameters are denoted by subscript " $\mathrm{M}$ " and the actual tank parameters are denoted with a subscript "A"):

\begin{tabular}{l|c|c|c}
\multicolumn{1}{c|}{ Parameters } & Scale Formula & Actual & Test \\
\hline Viscosity (flow cone - seconds) & $\mu_{M}=\mu_{A}$ & $2-5$ & $2-5$ \\
Fill Time (hours) & $\mathrm{t}_{\mathrm{M}}=1 / \mathrm{st} \mathrm{t}_{\mathrm{A}}$ & 6.25 & 1.56 \\
Volume (cubic yards) & $\mathrm{V}_{\mathrm{M}}=\mathrm{V}_{\mathrm{A}} / 64$ & 250 & $>3.91$ \\
Fill Rate (cubic yards per hour) & $\mathrm{Q}_{\mathrm{M}}=\mathrm{Q}_{\mathrm{A}} / 16$ & 40 & 2.50
\end{tabular}

The fill rate shall be used as the key test control parameter. A rate $2.50 \mathrm{yd}^{3} / \mathrm{hr}$ is equivalent to $8.4 \mathrm{gpm}$, or more practically $8-10 \mathrm{gpm}$. The sludge shall be placed at a depth of approximately $1 / 4$ to $1 / 3$ inches. This corresponds to $71-94$ gallons in the test tank.

\subsection{GENERAL TEST METHODS}

\subsection{Initial Conditions .}

\subsubsection{Test Tank Specifications}

5.1.1.1 The shape shall be circular.

5.1.1.2 The diameter of the test tank shall be 23-25 feet. 
HLW-HLE-97-0077

Revision 1

Page 4

5.1:1.3 The height of the test tank shall be at least 24 inches.

5.1.1.4 The test tank shall be capable of withstanding 2 feet of hydrostatic head without visible bulging.

5.1.1.5 The surface shall be flat with the slope not exceeding $1 / 4$ inches over 20 feet.

5.1.1.6 The contact surface shall be smooth with surface irregularities not exceeding 1 inch.

5.1.1.7 The test tank shall be watertight

5.1.1.8 The test tank must have unobstructed access from the top.

5.1.1.9 The test tank must be chemically resistant to a $\mathrm{pH}$ of 11-12.

\subsubsection{Simulated Sludge}

5.1.2.1 Sludge shall be obtained from either TNX or CTL. This sludge shall be spiked with sodium oxalate, sodium carbonate, sodium hydroxide, copper sulfates and sodium sulfate or equivalent as prescribed by SRTC.

5.1.2.2 Approximately 71-94 gallons of the simulated sludge shall be poured and spread into the bottom of the test tank. The volume of the poured sludge shall be measured to within $1 / 2$ gallons accuracy using a volumetric calculation.

\subsubsection{Grout Preparation}

5.1.3.1 The grout shall be prepared in accordance with Specification C-SPP-F-00038 Mix Identifier 3TK-X-S-0-R.

\subsubsection{Delivery Conditions}

5.1.4.1 The grout shall be capable of being delivered at a rate of 8-10 gallons per minute. Flowrate averaging over a time period of 10-15 minutes is acceptable.

5.1.4.2 The distance from the edge of the test tank to the pour location shall be between $1-2$ feet.

5.1.4.3 The grout shall be sufficiently retarded to prevent premature setting during the test but not so retarded as to prevent eventual hardening. 
5.1.4.4 The grout shall be continuously agitated in temporary storage prior to and during the grout pours.

\subsection{Test Methodology}

5.2.1 Prepare the test tank, sludge, and grout as described in the Section 5.1. Refer to Sketch 1.

5.2.2.1 Pour grout material at station no. 1 until the size of the edges of the grout mat has spread to over $1 / 2$ to $3 / 4$ of the distance to the next station or as directed by the HLWE engineer.

5.2.2.2 Repeat previous step for stations no. 3, then 5, then 2, then 4 , and then 6 .

5.2.2.3 Pour grout material at station no. 7 until the central area is covered.

NOTE: Cover the test tank with a plastic tarp to prevent evaporation if sludge measurement will be delayed.

5.2.2.4 Allow grout in the test tank to harden.

5.2.2.5 Photograph or videotape final sludge configuration.

5.2.2.6 Remove as much of the loose sludge as possible from the test tank and place in watertight containers. Measure the sludge volume to within $1 / 2$ gallons.

5.2.2.7 Photograph or videotape the grout profile in the test tank.

5.2.2.8 Replace to the extent practical the sludge back into the test tank to achieve the original profile.

5.2.2.9 Cover or spray the loose sludge in the test tank with the dry reducing grout recipe provided by SRTC.

5.2.2.10 Pour $3 \frac{1}{2}-6$ yards of grout at the center location (station no. 7) at the rate specified above.

5.2.2.11 Allow the grout to cure at the direction of C. A. Langton (SRTC). 
WSRC-TR-97-0101

Revision 0

Appendix A

Page 20

HLW-HLE-97-0077

Revision 1

Page 6

5.2.2.12 Drill core samples in the test tank as required by the attached Sampling and Analysis Plan.

5.2.2.13 The grout/sludge mats shall be broken up and disposed of properly. Photographs or videotape shall be taken of the broken pieces.

\subsection{DATA COLLECTION}

6.1 The total volume of sludge introduced into the test tank shall be recorded to within $1 / 2$ gallons.

6.2 The volume of sludge in the test tank not incorporated (i.e. liquid sludge) in the grout prior to top dressing treatment shall be recorded to within $1 / 2$ gallons.

6.3 Estimate of area of grout covered by liquid sludge and map of locations in the test tank.

6.4 The flow cone measurement of the grout shall be taken periodically to verify fluidity as determined by the HLWE engineer.

6.5 The operation shall be videotaped and/or photographed.

6.6 Cores shall be analyzed as required in the Sampling and Analysis Plan (attached) to quantify the degree of sludge/grout mixing.

\subsection{ACCEPTANCE CRITERIA}

Data collection as described in the attached Sampling and Analysis Plan and Section 6.0 above.

\subsection{DELIVERABLES}

Technical Report with test results and conclusions.

\subsection{REFERENCĖS}

9.1 Correspondence from M. C. Roco to R. Campbell, "Closure of Tank \#20 in the High Level Waste Tank Farm Facility (AB94260S)," March 8, 1997.

9.2 Construction Technology Laboratories, Inc. (CTL), Final Report, "Development of Reducing Grout for Closure of Savannah River Site Tank \#20," October, 1996. 


\section{HLW-HLE-97-0077}

Revision 1

Page 7

9.3 SRS Specification, C-SPP-F-00038, "Tank Closure - Furnishing and Delivery of Tank Fill Materials \& Reducing Grout (U), "Revision 2.

9.4 C. A. Langton to T. B. Caldwell, "Sampling and Analysis Plan for the March 14, 1997 Simulated Tank 20 Grout Pour (U)," SRT-WPT-97-0166, March 12, 1997.

9.5 Telephone conversations with Dr. M. C. Roco and T. B. Caldwell, March 17 and March 18, 1997. 
HLW-HLE-97-0077

Revision 1

Page 8

\section{Grout \& Sludge Distribution Testing}

\section{Form Design}

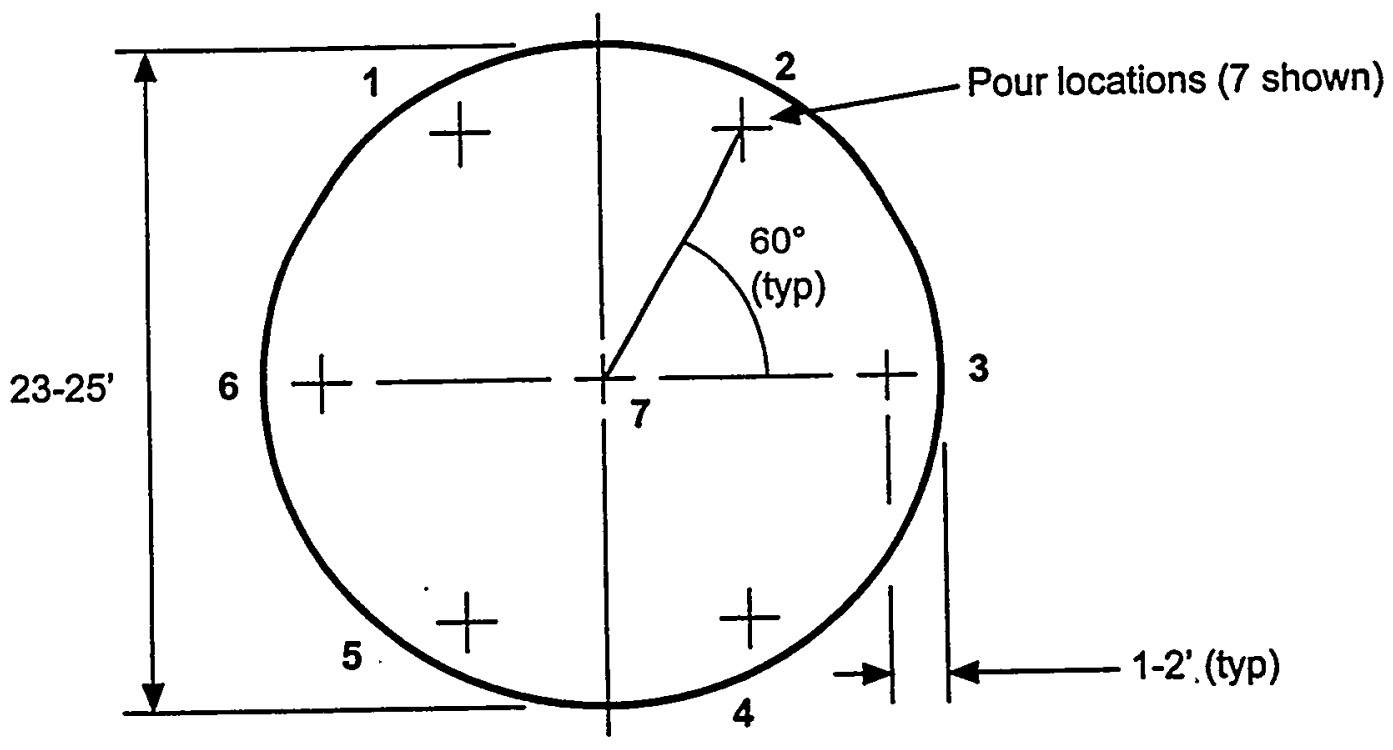

Plan View

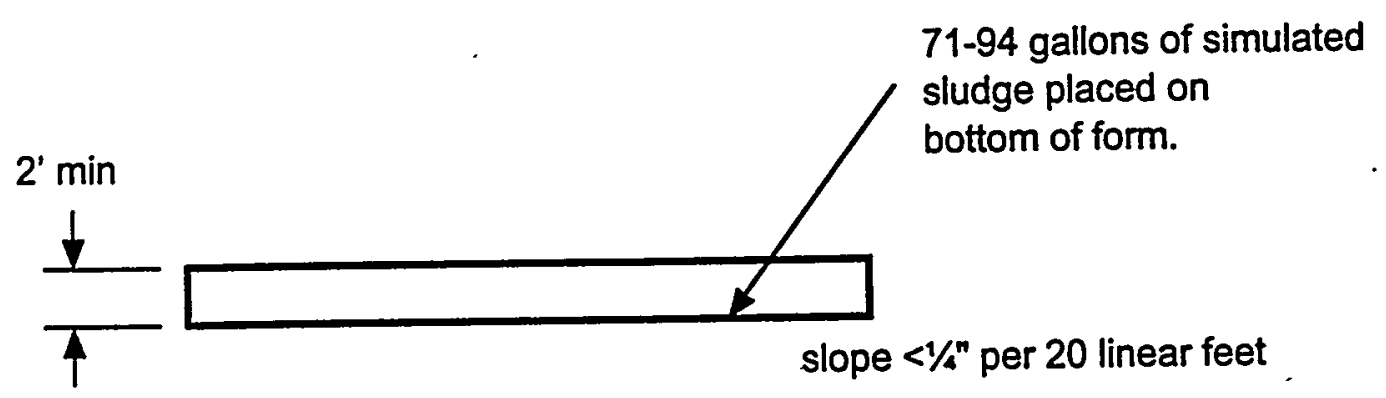

Elevation View

Notes:

1. Form shall be watertight

2. Form shall have free access from top

SKETCH NO. 1

3. Form shall be chemically resistant to $\mathrm{pH} 11-12$. 
WSRC-TR-97-0101

Revision 0

Appendix A

Page 23

HLW-HLE-97-0077

Revision 1

Page 9

WESTINGHOUSE SAVANNAH RIVER COMPANY SAVANNAH RIVER TECHNOLOGY CENTER
SRT-WPT-97-0166

March 12, 1997 cc: W. E. Stevens, 773A

B. T. Butcher, 773-43A

B. Nore, 773-62A

J. Newman, 742-6G

N. Rajendran , 730-1B

File:2copies

To: T. B. Caldwell, 742-4G

From: C.A. Langton, 773-43A

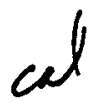

SAMPLING AND ANALYSTS PLAN FOR THE MARCH 14, 1997 STMULATED TANK 20 GROUT POUR (U)

\section{SUMMARY}

Two sampling strategies are proposed for sampling the simulated sludge-grout flow test in the swimming pool forms. This sampling plan is intended to supplement the Grout Pour Test Plan, 3-14-97.

- Option A - Random sampling on a grid pattern A grid pattern for round sample containers will be used. The container will be divided into 8 equal sectors and a random sample will be taken form each sector.

- Option B - Judgmental sampling based on examination of the final experiment. The swimming pool can be divided into 8 equal sectors. A sampled will be obtained from each sector.

Cores will be sectioned into dises 4- inches in length. Coring and core sectioning will be conducted by BSRI (coordinator. L. P. Salyor). Grid and sector layouts and sample labeling and tracking will be provided by B. Nora, WSRISMP. Samples will be analyzed by GEL, Charleston, SC with J. Crawford, (GEL STR) serving as the GEL point of contact.

Option B is suggested at this time based on the current understanding of the test objectives. However, both options will be prepared for implementation. 
WSRC-TR-97-0101.

Revision 0

Appendix A

Page 24

HLW-HLE-97-0077

Revision 1

Page 10

SRT-WPT-97-0166

March 12,1997

Page 2 of 4

Visual characterization of the macroscopic features of this test pour will be made by WSRC/HLWE and SRTC and possibly one or more independent consultants. Visual characterization of the cores will be made by HLWE/SRTC/SMP personnel. Photographs will also be taken to document the experiments and of the samples.

\section{APPROACH}

The grout simulated studge flow patterns will be observed and documented while the experiment is in progress. After the two forms have been fill to the desired level, the appearance of the sludge and grout will be recorded. If dry material is added to sludge on top of the grout, observations will be made to document the condition of the this final configuration. The swimming pool forms will be covered and allowed to cure.

$$
\text { QSdirected by SRTC TRC 3Heling }
$$

The grout will be checked wrey 12 hourf to determine whether it has set. Coring will take place no sooner than 48 hours after the grout (and dry sorbent material) has been placed. If the grout has not gained sufficient strength to enable efficient coring, additional curing time will be allowed. 24 hours will be the smallest time increment for reevaluating the readiness for coring. The condition of the grout with respect to strength required for coring will be made by $C$. Langton. Control samples of the grout will be taken during the experiment to provide information on the strength gain. (Raytheon personnel will be responsible for taking these samples and for subsequent compressive strength testing.)

Cores ( 3 inch diameter for the entire depth of the material in the swimming pool form) will be obtained at the approximate locations indicated for Options A or B. The final decision on the core location will be made after the completed experiment is visually observed. Core locations will be marked by $C$. Langton (or designee) prior to the sampling. Cores will penetrate the entire depth of the grout-sludge experiment. In the event that cores break during the sampling process, the decision to contime or to move to a near by location will be made by $C$. Langton (or designec).

Wet coring will be conducted by on-site BSRI personnel (L. P. Salyer will arrange and coordinate this activity.) BSRI personnel will also cur the cores into $2-4$ inch sections which will be sent to an off site vendor (GEL, Charleston, SC) for total Ni and total $\mathrm{Cu}$ analyses. GEL picks up samples at SRS at 1200 hours, Monday through Friday. Emergency turn around time is 3 working days. (If the samples leave SRS at noon on Monday March 17, analytical results will be FAXED to WSRC on Thursday Ṃarch 20.)

Analytical results for total $\mathrm{Ni}$ and $\mathrm{Cu}$ concentration will be tabulated reported to HLWE within 24 hours after they are received from GEL. This allows time for interpreting and summarizing the data. 


\section{WSRC-TR-97-0101}

Revision 0

Appendix A

Page 25

HLW-HLE-97-0077

Revision 1

Page 11

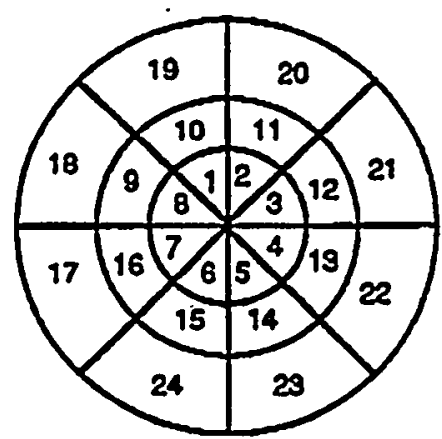

Container dlvided into an imaginary grid.

\section{Sample Collection}

The sampling approach to be used will be the two-dimensional simple random sampling strategy, which can usually yield a more precise sampling when fewer samples are collected. The strategy involves dividing the top surface of the waste into an imaginary grid as shown above. Then selecting grid sections for sampling using random-number.tables or random-number generators and sampling each selected grid. point in a vertical manner along the entire length from top to bottom using a sampling device

\section{OPTION A RANDOM SAMPLING PLAN}


HLW-HILE-97-0077

Revision 1

Page 12

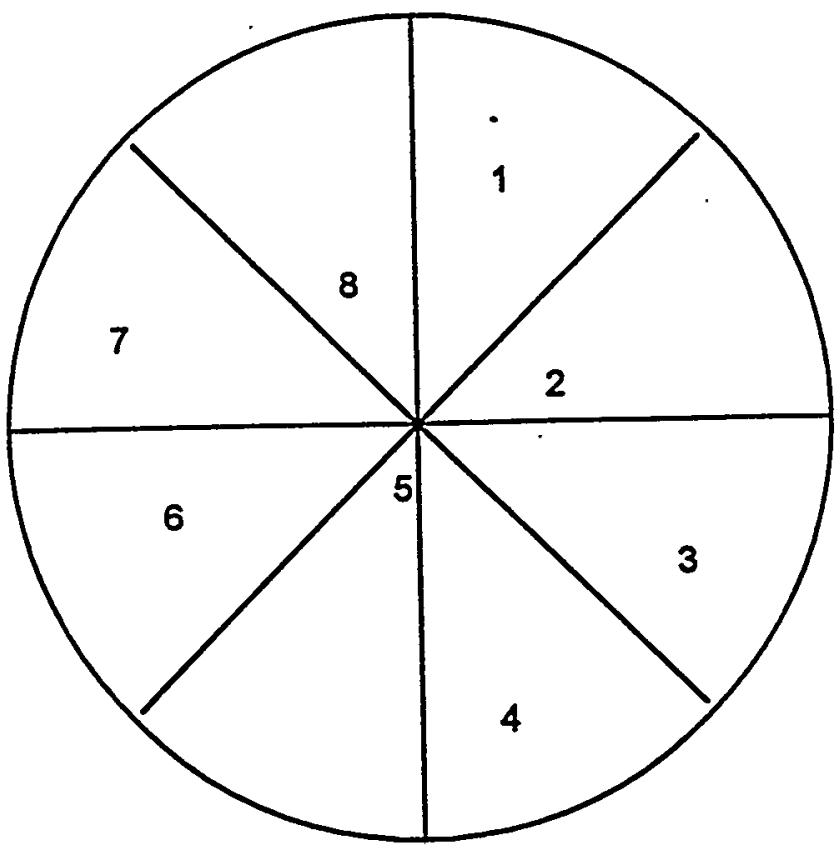

Container divided into sectors.

\section{Sample Collection}

The sampling approach to be used will be to divide the container into equal sectors and to use judgment to determine the location of a sample point within each sector. 


\section{APPENDIX B \\ FLOW CONE DESIGN SPECIFICATION}

\section{KODAN 304 \\ METHOD OF CONSISTENCY TEST FOR NON-SHRINKAGE MORTAR}

This test shall be performed using J-funnel.

1. Test Instruments

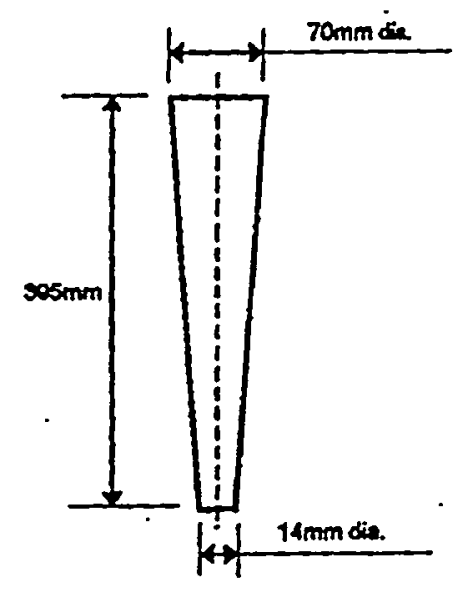

a) Funnel is to be made of S.S. with an inside diameter of $70 \mathrm{~mm}$ at the top, $14 \mathrm{~mm}$ at the bottom and a height of $395 \mathrm{~mm}$.

b) . Funnel stand

c) Leveling spatula

d) Stopwatch

2. Test Method

The tests shall be performed twice in succession as indicated below:

a) The testing is to begin by wetting the inside surface of the apparatus with water.

b) A finger is to be placed over the opening at the bottom of the apparatus to prevent the reducing grout to pass. The reducing grout is to be added by pouring into the top opening of the apparatus. The reducing grout is then to be leveled or smoothed at the top by a spatula.

c) Release the finger from the bottom opening and time, by use of a stopwatch, the flow as it exits the apparatus. Timing is to stop when the first pause in the flow is noticed or until content is emptied.

d) Flow shall be determined by performing the test twice in succession and averaging the timed values. 
WSRC-TR-97-0101

Revision 0

Appendix C

Page 28

Total Area $=452 \mathrm{ft}^{2}$

APPENDIX C

Sludge Area $=155 \mathrm{ft}^{2}$ or $34 \%$

\section{SLUDGE AND GROUT MAP}

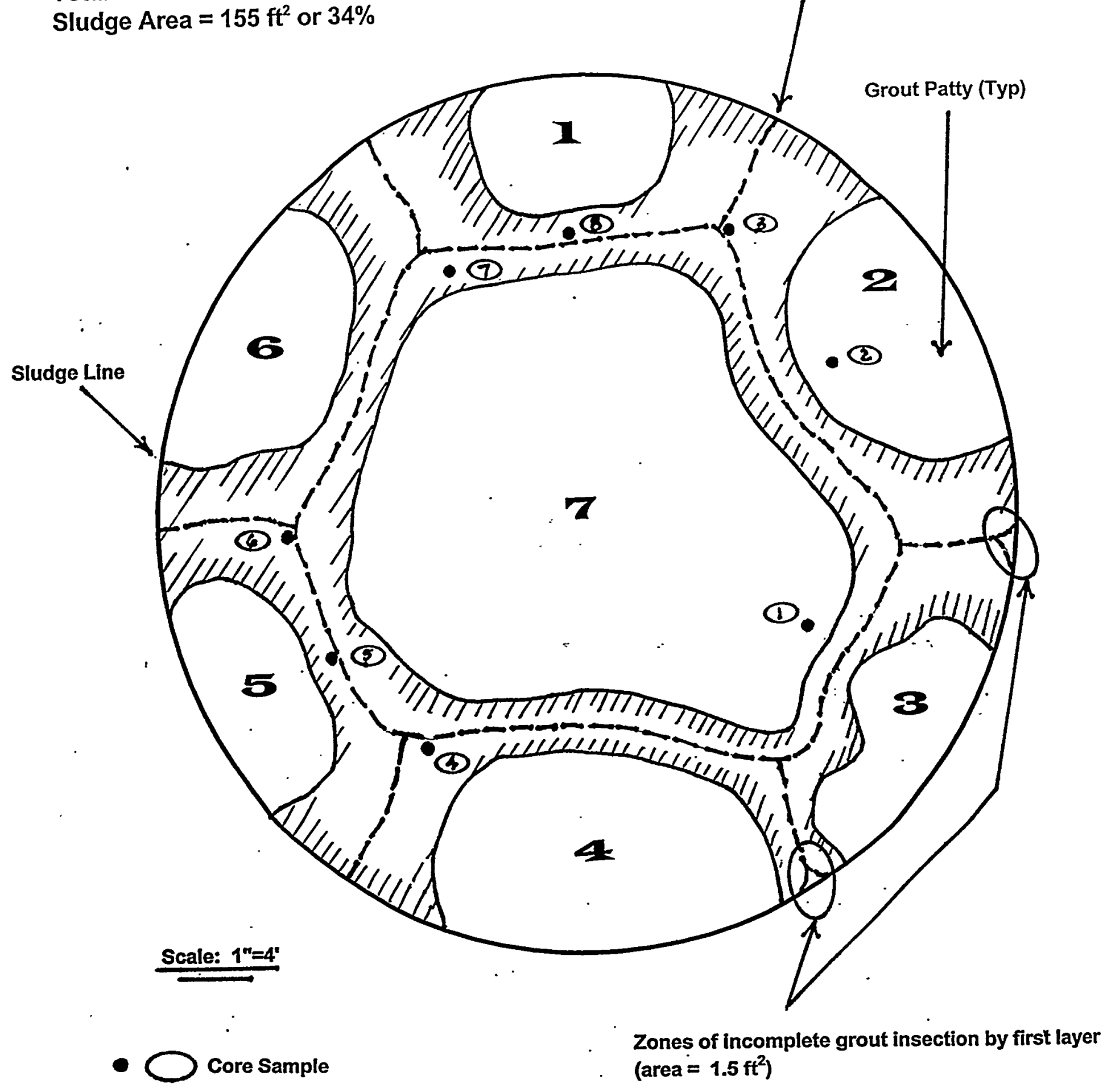


WSRC-TR-97-0101

Revision 0

Appendix D

Page 29

APPENDIX D

FINAL GROUT FLOW PATTERN

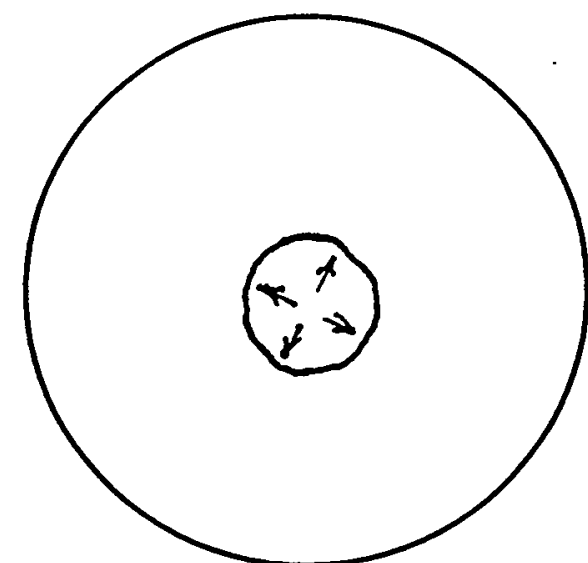

1. Start of Final Grout Pour

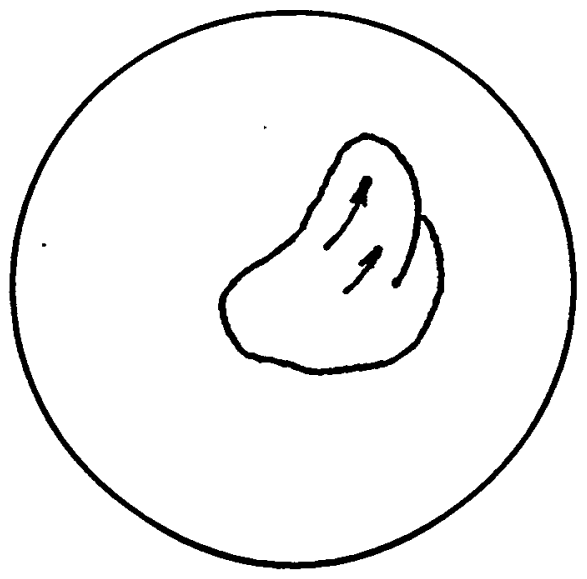

3. Flow begins on adjacent side

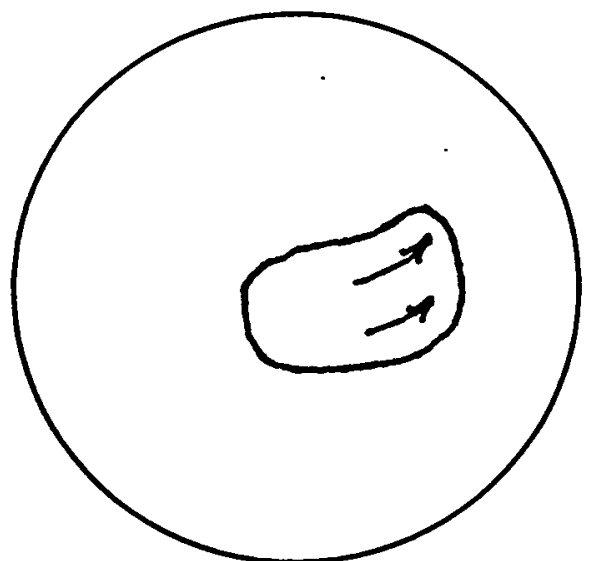

2. Grout mounds and slips to one side

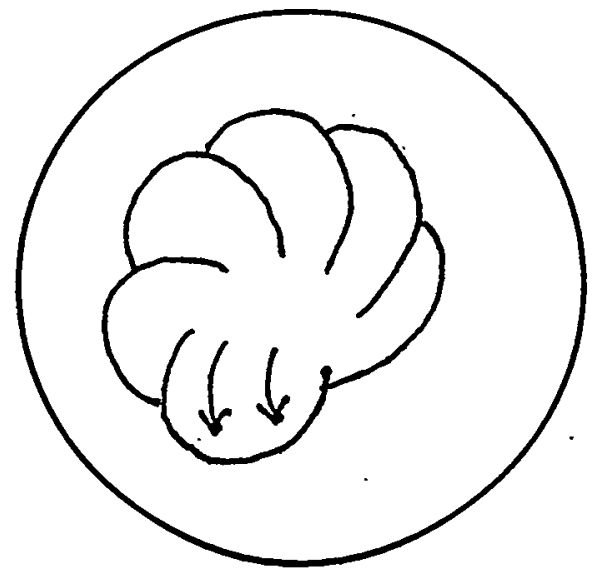

4. Pattern forms in counter clockwise motion

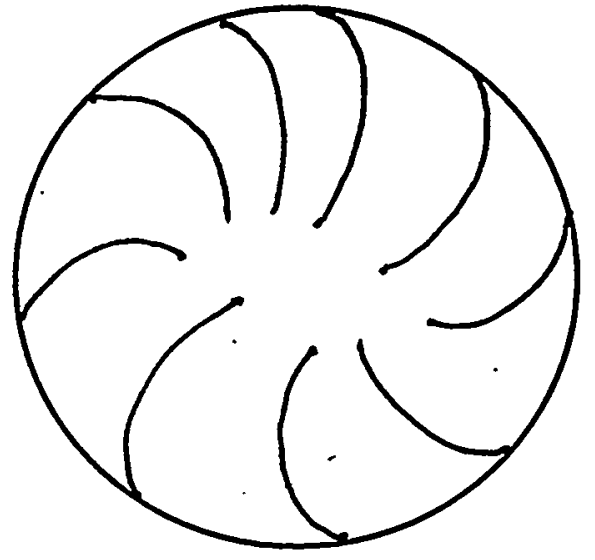

5. Final pour pattern 
WSRC-TR-97-0101

Revision 0

Appendix E

Page 30

APPENDIX E

NINE

PHOTOGRAPHS 


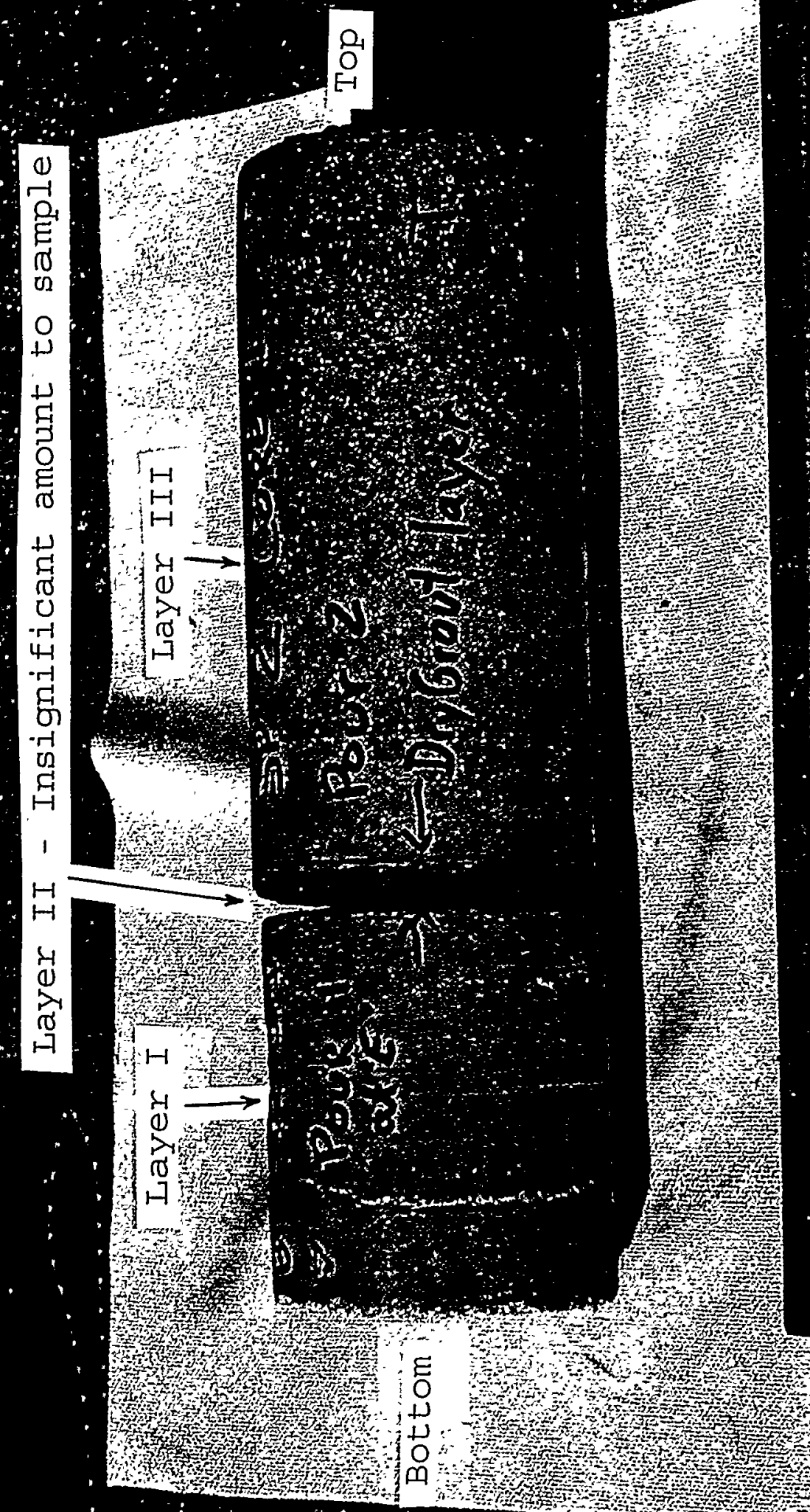

WSRC-TR-97-0101

Revision 0

Appendix E

Page 31

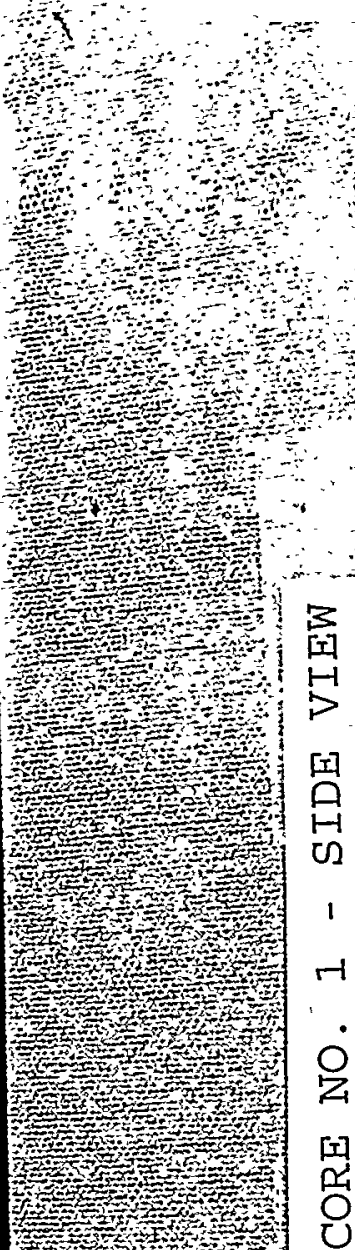
Now Fond int

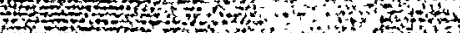

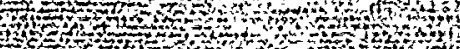
S 2 .

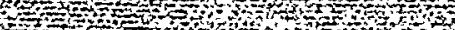

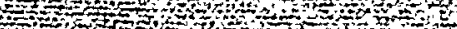

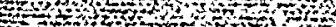
作,

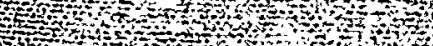

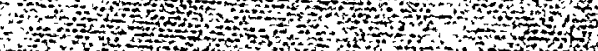

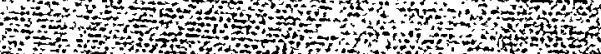
A

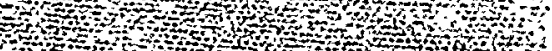




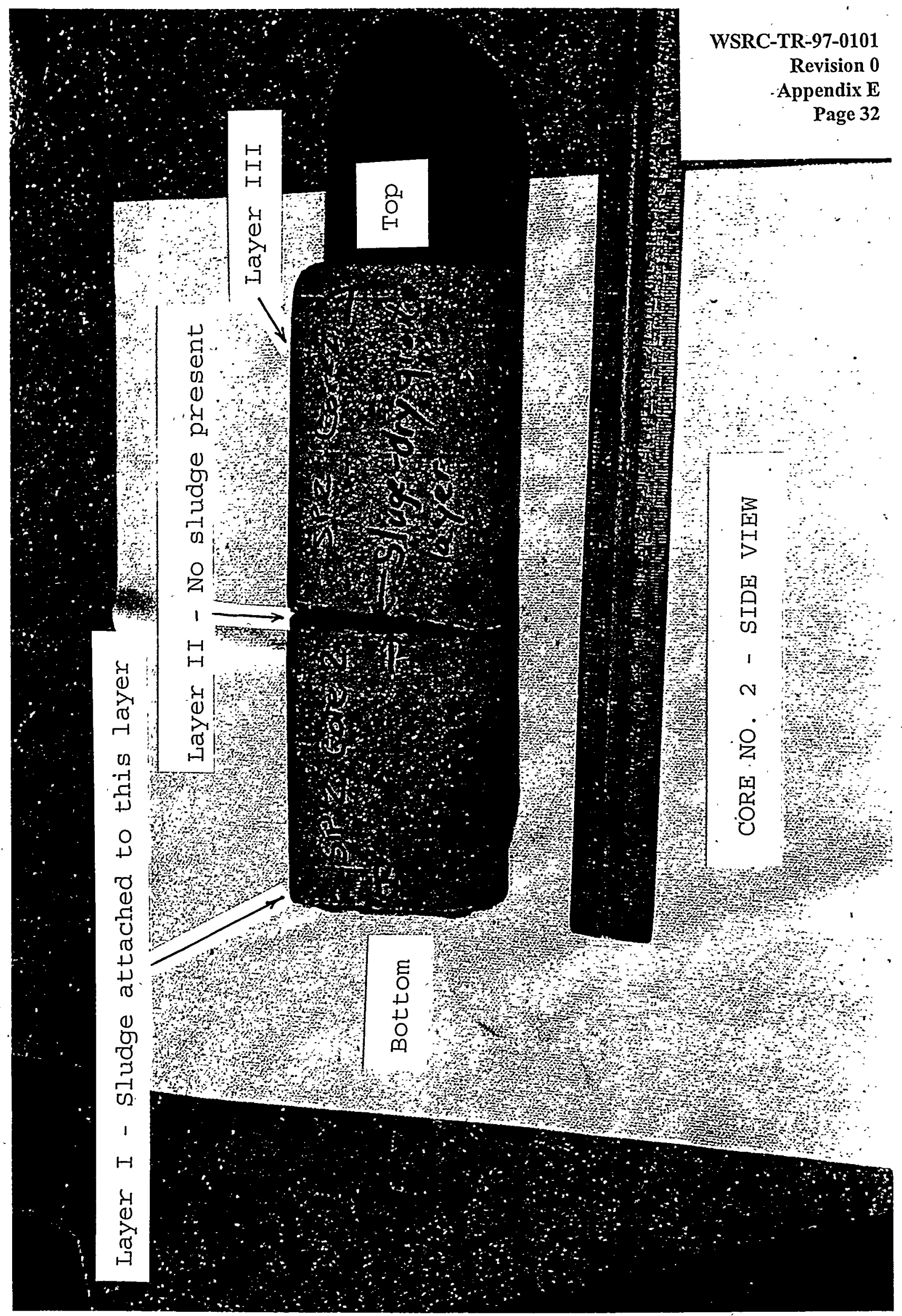




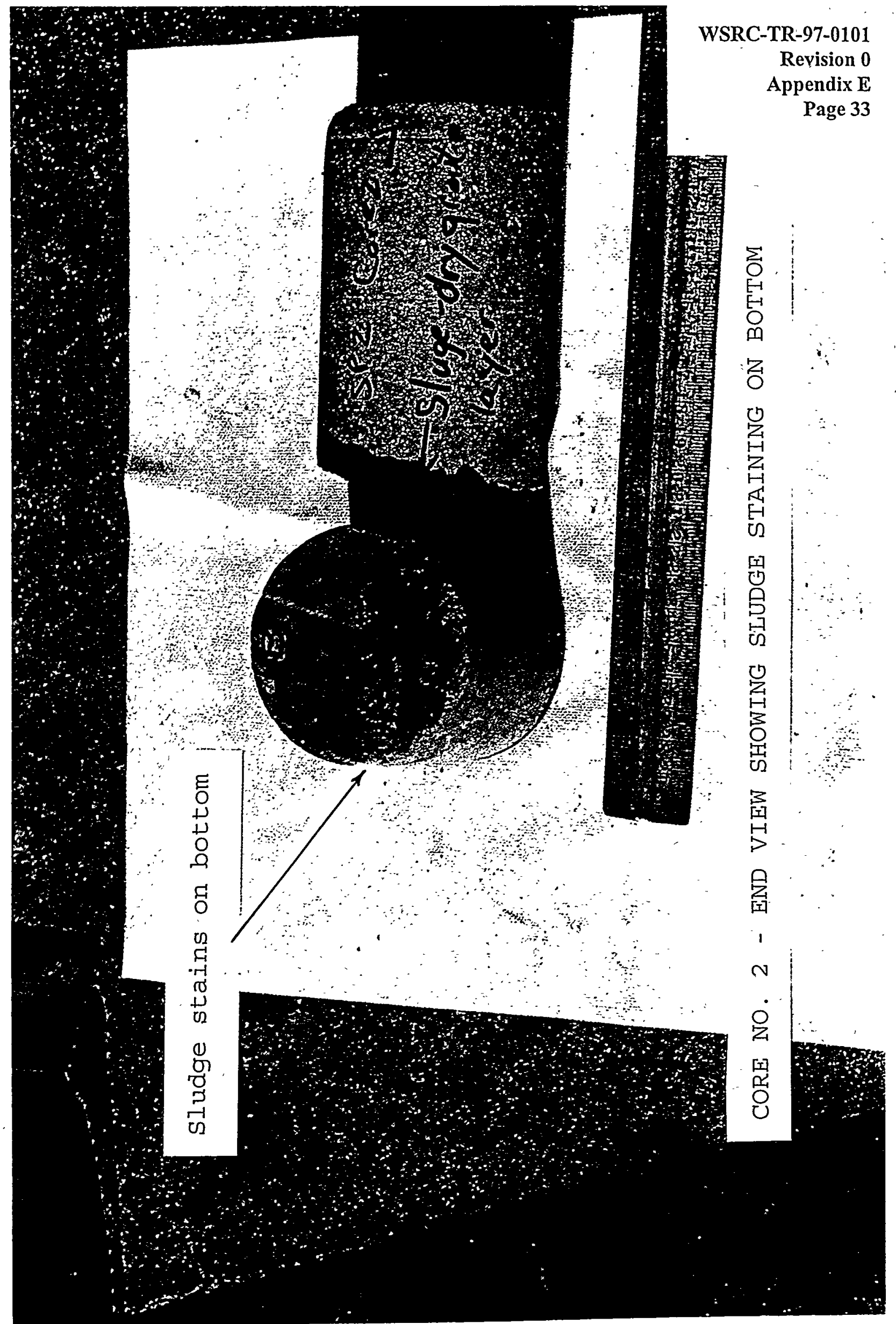




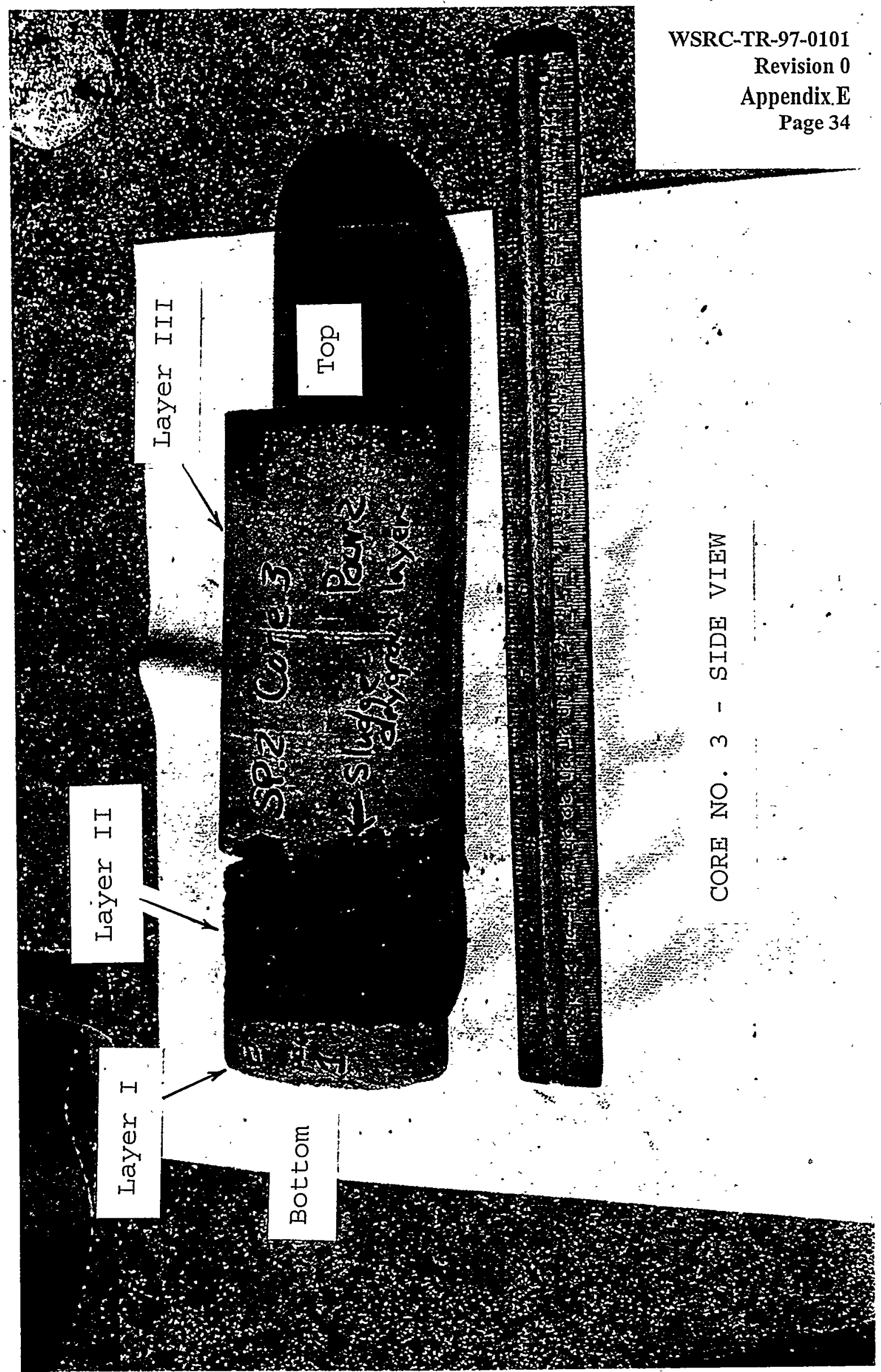




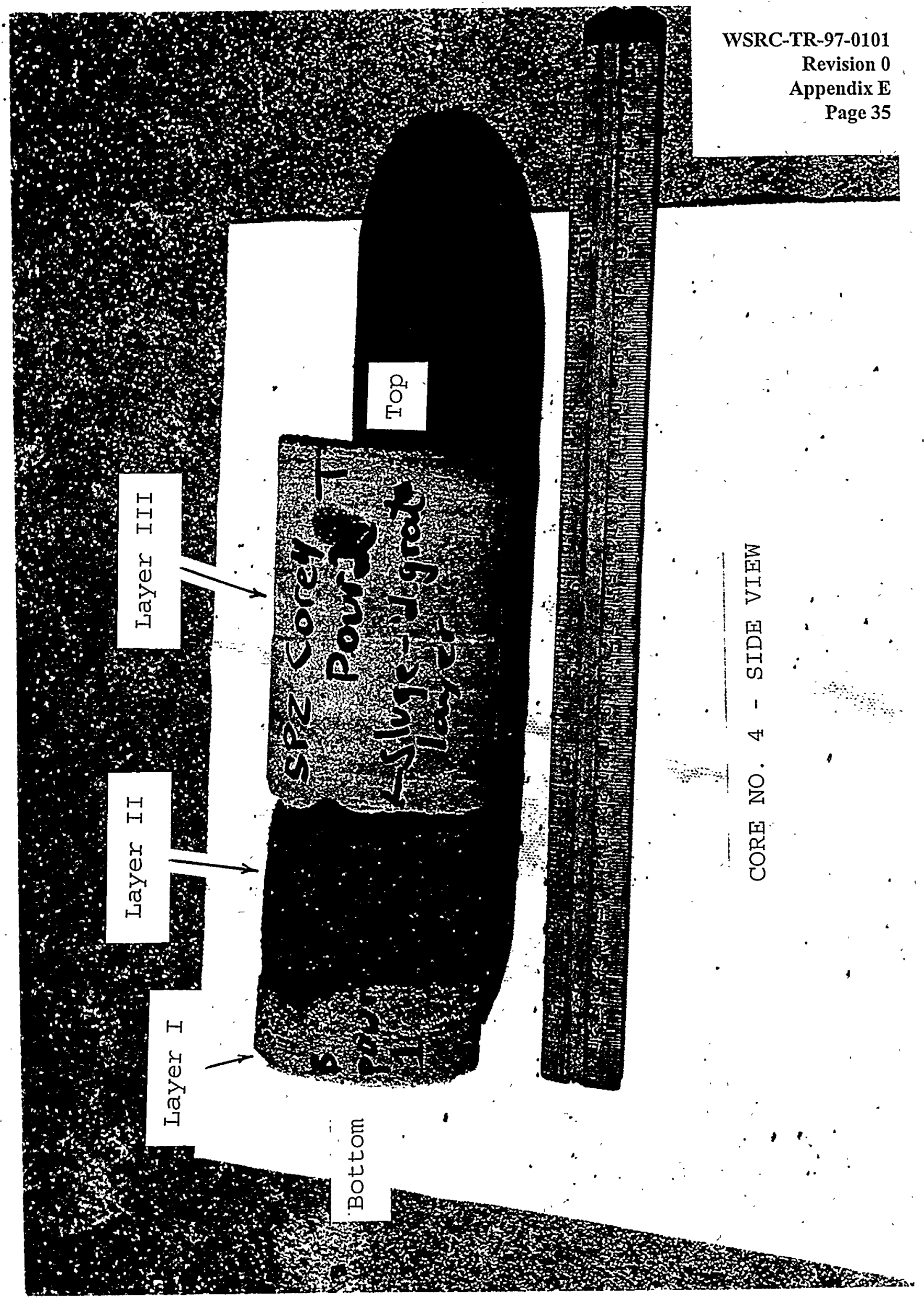




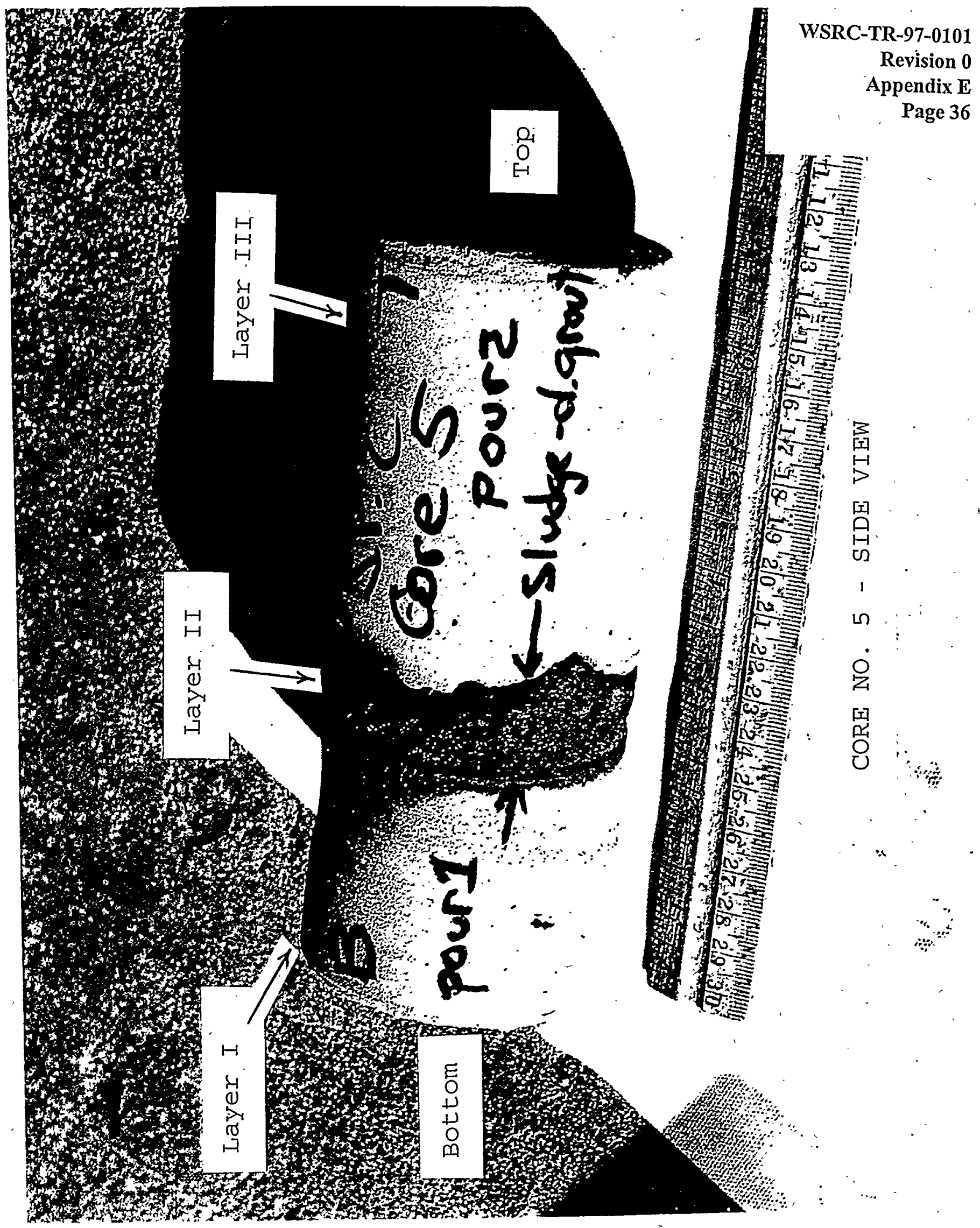


WSRC-TR-97-0101

Revision 0

Appendix E

Page 37
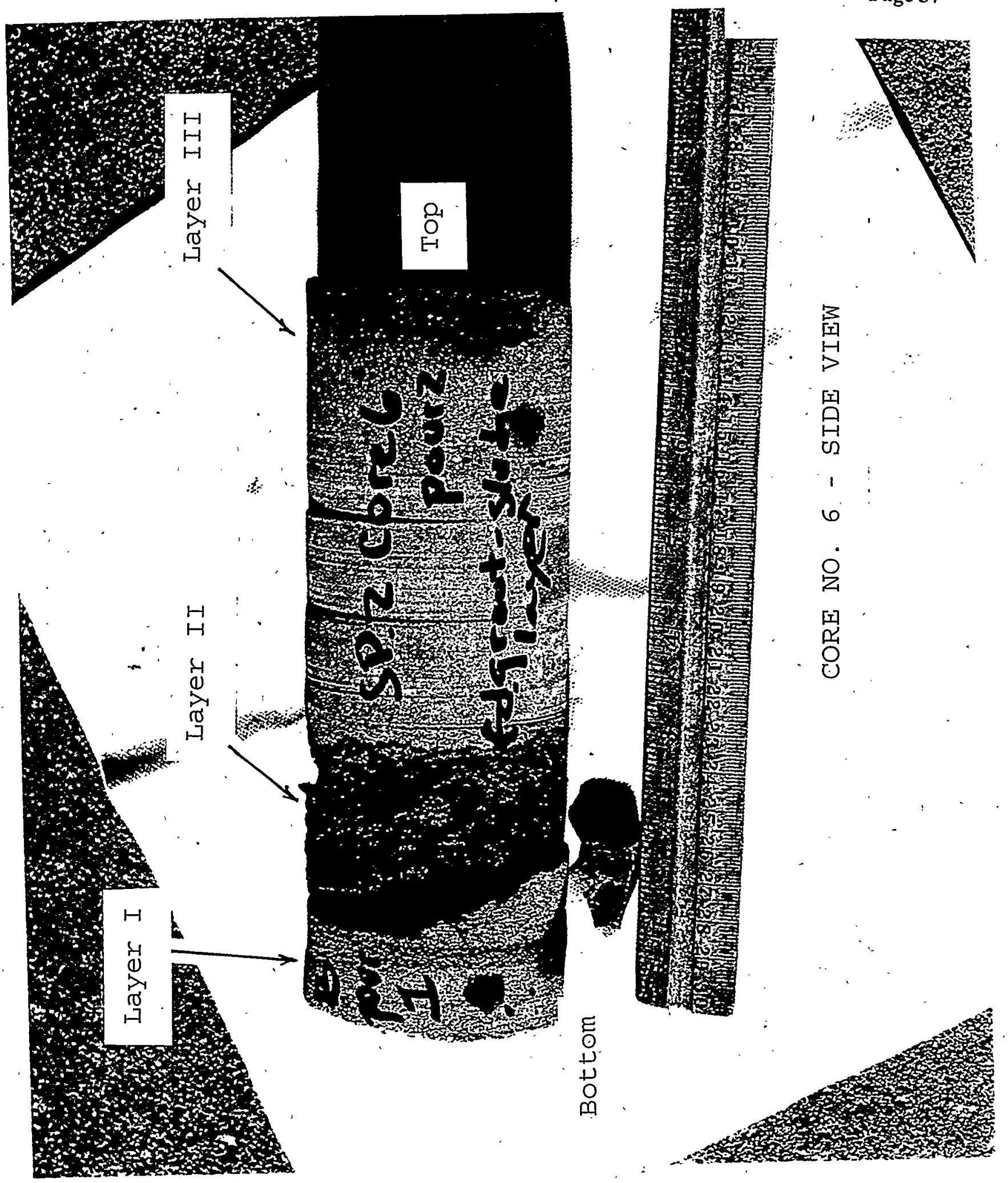


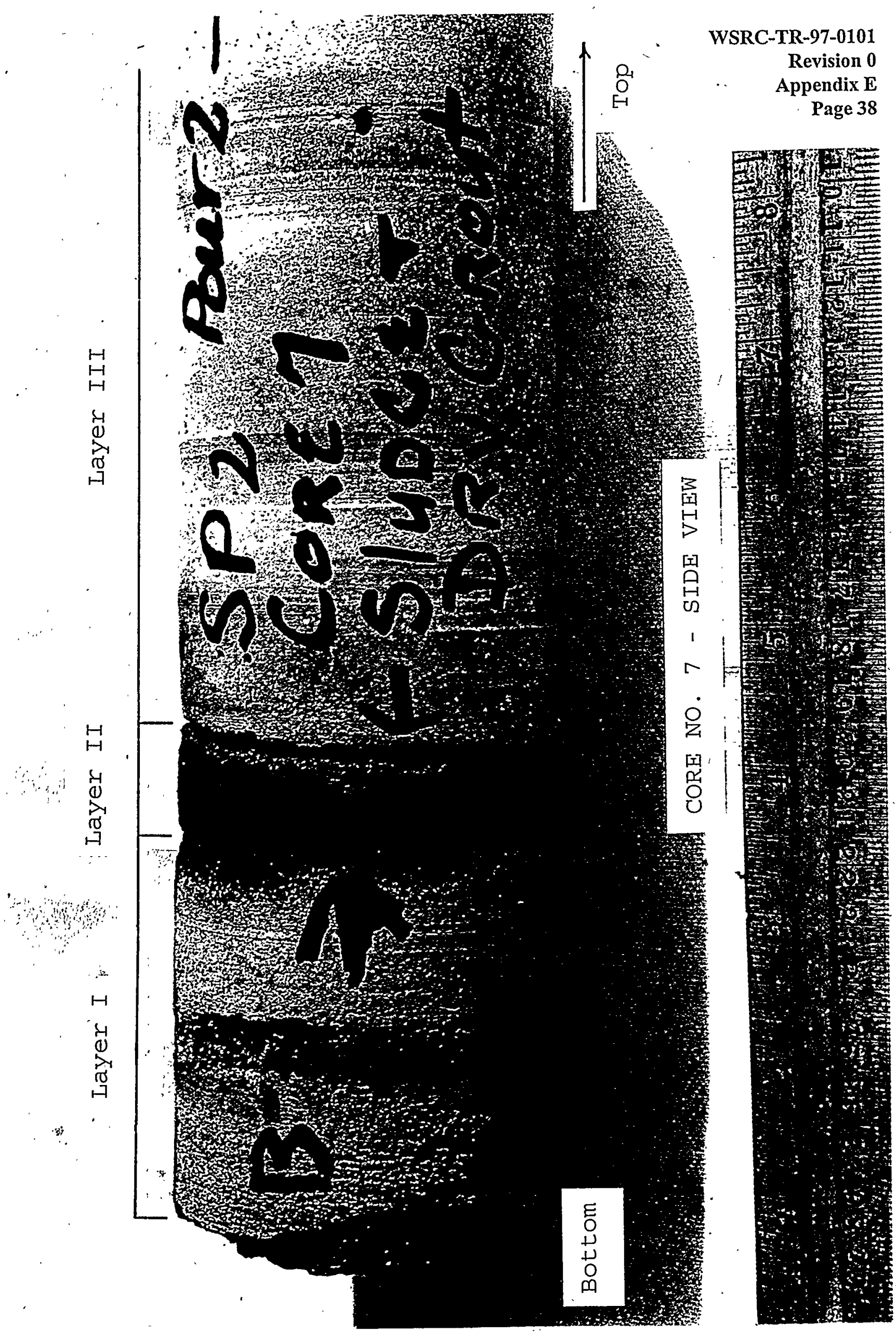


WSRC-TR-97-0101

Revision 0

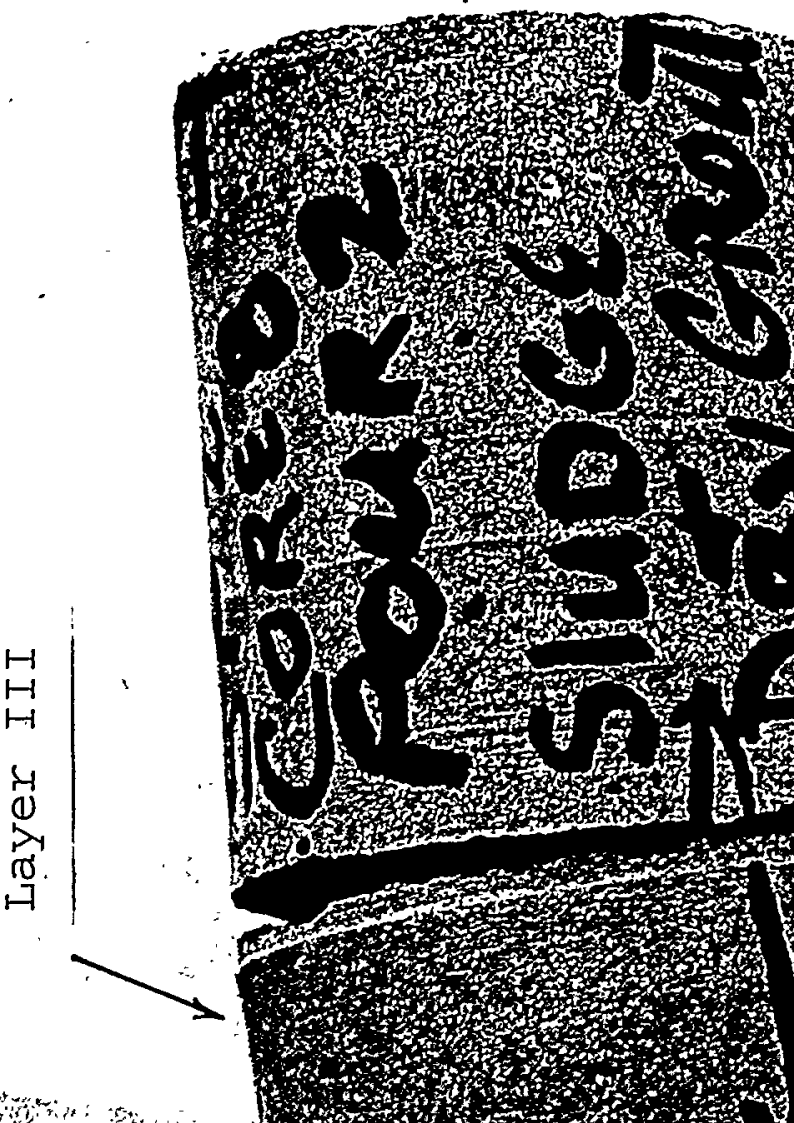

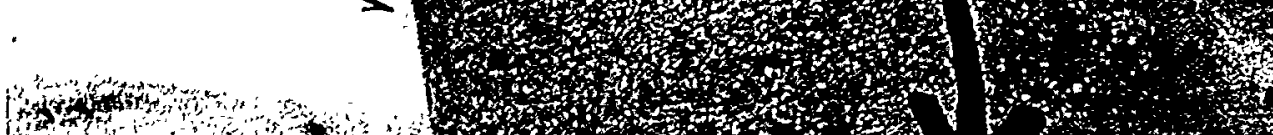

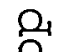

Appendix E

Page 39

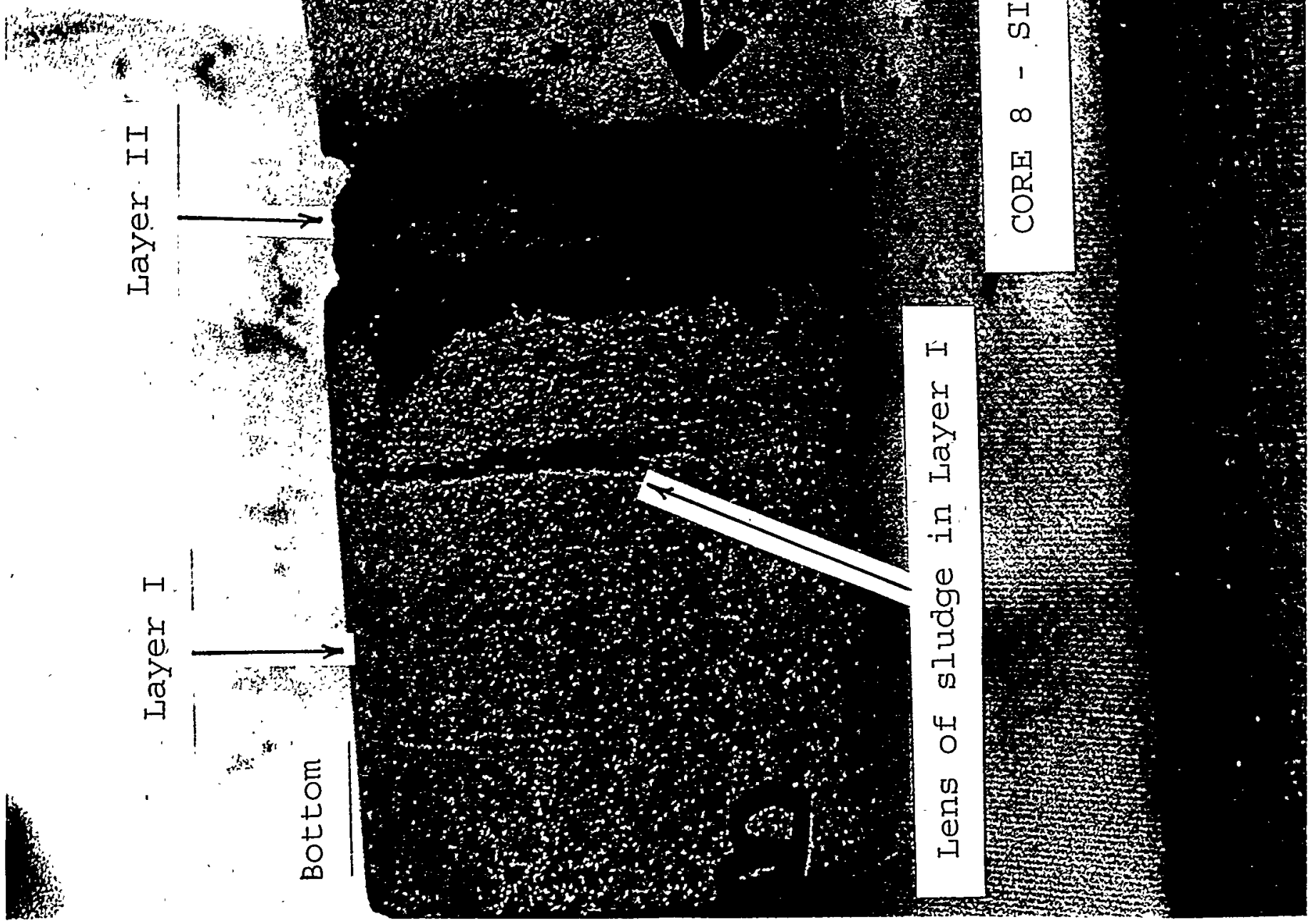

